\title{
Coin Reconsidered: The Political Alchemy of Commodity Money
}

\section{Citation}

Christine Desan, Coin Reconsidered: The Political Alchemy of Commodity Money, 11 Theoretical Inquiries in Law, Article 13 (2010).

\section{Published Version}

doi:10.2202/1565-3404.1245

\section{Permanent link}

http://nrs.harvard.edu/urn-3:HUL.InstRepos:3685820

\section{Terms of Use}

This article was downloaded from Harvard University's DASH repository, and is made available under the terms and conditions applicable to Open Access Policy Articles, as set forth at http:// nrs.harvard.edu/urn-3:HUL.InstRepos:dash.current.terms-of-use\#OAP

\section{Share Your Story}

The Harvard community has made this article openly available.

Please share how this access benefits you. Submit a story.

\section{Accessibility}




\section{Theoretical Inquiries in Law}

Volume 11, Number 1

January 2010

Article 13

Money Matters: The LAw, ECONOMics, and Politics of CURRENCY

\section{Coin Reconsidered: The Political Alchemy of Commodity Money}

Christine Desan*

Copyright (c)2010 The Berkeley Electronic Press. All rights reserved. 


\title{
Coin Reconsidered: The Political Alchemy of Commodity Money
}

\begin{abstract}
Christine Desan*
Medieval coin plays an essential role in the imagined history of money: it figures as the primal "commodity money" - a natural medium, spontaneously adopted by parties in exchange who converge upon a metal like silver to represent the value of other goods. As a natural medium with a price objectively established through trade, commodity money appears to offer an independent means of measure in the market. But as the history offered here reveals, medieval money was nothing like its imagined alternative. England's early coin became a medium when the government began to spend and tax in that unit of account, took coin as a mode of payment, and allowed it to be transferred between people in the meantime. Individuals participated in the arrangement, paying for coin in exchange for the unique quality — liquidity — that set money apart from a commodity. That quality was orchestrated by the very channels that brought public and private together in the project of making a medium. In fact, insofar as the English equated money with the commodity it contained, they engineered instability into the heart of their medium. Depreciating coin - diluting its commodity content - offered a cure. It also confirmed that coin had never been the "commodity money" imagined in later accounts. Coin was, instead, a constitutional medium, one that related the government to its participants and thus helped to configure the world it appeared merely to measure.
\end{abstract}

* Professor of Law, Harvard Law School. I wish to thank Mo Chen, Lauren Coyle, Ron Harris, Roy Kreitner, Nicholas Mayhew, Karl Shoemaker, and Ryan Taliaferro for their illuminating comments, the participants in the Cegla Conference on Money Matters for the great discussion, and the staff and students of Theoretical Inquiries in Law for their superb editing. 


\section{INTRODUCTION}

In 1945, only months after he had been released from a prisoners-of-war camp, R.A. Radford set down an account of his experience there, describing the political economy of the camp and documenting how prisoners began to exchange goods by using cigarettes as money. Radford's POW camp was a free market in microcosm, available in magnificent simplicity and clarity. His essay became an iconic account of the way that one commodity there, cigarettes - emerged to act as a currency among others, allowing trades between individuals that made everyone better off.

The power of Radford's account lay in its ability to illuminate "the growth of economic institutions and customs in a brand new society." The camp was "small and simple enough to prevent detail from obscuring the basic pattern and disequilibrium from obscuring the working of the system." As Radford explained, his example also demonstrated "the universality and the spontaneity of this economic life." ${ }^{11}$ Economists widely agreed. An article in the 1991 Journal of Economics Education recommended that the Radford essay be taught in intermediate economics courses. Textbooks invoked the article in their explanations of money. The POW camp offered the example of "an actual economy," a way to vitalize abstract models with real world facts while retaining "the virtue of simplicity."2

The case study appeared marvelously designed for that use. Prisoners received "roughly equal" shares of essentials from Red Cross food parcels. The groceries, which included tinned milk, jam, butter, cigarettes, biscuits, canned beef, chocolate, sugar, and other items, arrived regularly. (POWs also received clothing, toiletries, and cigarettes from private parcels, introducing some inequality.) Prisoners immediately began trading their items. As Radford saw it, they quickly recognized exchange "as a more equitable means of maximizing individual satisfaction" than the "goodwill" that came from giving and accepting gifts. The appearance of money occurred within a month: "Most trading was for food against cigarettes or other foodstuffs, but

1 R.A. Radford, The Economic Organization of a P.O.W. Camp, 12 EconOMICA 189, 190 (1945).

2 Donald W. Katzner, Unity of Subject Matter in the Teaching of Intermediate Microeconomic Theory, 22 J. ECON. EDUC. 154, 160 (1991); see also, e.g., Michael Salemi, Discussion Questions, http://www.unc.edu/ salemi/Econ101/Radford\%20 Discussion\%20Questions.pdf (last visited Apr. 2, 2009); N. GREGORY MANKIW, MACROECONOMICS 157 (4th ed. 2000). 
cigarettes rose from the status of a normal commodity to that of currency." Once cigarettes became "the standard of value," cigarette prices became well known throughout the camp and tended towards equality. ${ }^{3}$

The exchange created an embryonic market, one that Radford understood as a product of "spontaneous operation," where "prices were fixed by the operation of supply and demand." When tins of oatmeal, once a rare and prized luxury in the food parcels, became commonplace, their price fell. Demand for cocoa dropped during hot weather, while demand for soap rose. And when the prisoners figured out how to distill raisins and sugar into liquor, prices on the dried fruit market improved radically. All of that was as it should be and worked well as long as the money supply remained stable. By contrast, fluctuations in that supply created a "fundamental instability" that caused most of the prisoners' "economic troubles." When many prisoners all at once received packages from home full of cigarettes, the amount of "money" in circulation jumped and prices rose. And when the stress of wartime - heavy air raids near the camp, for example — drove them to smoke their currency, the amount in circulation dropped and prices fell. ${ }^{4}$

There were other threats to the pristine market created with commodity money. Soldiers sometimes re-rolled cigarettes to remove some of the tobacco content, inflicting "all the inconveniences of a debased currency" on their mates. At other times they shook out a bit of tobacco, just as coin clippers used to take slivers of silver, to amass later into a new piece of currency. And then there was the prisoners' troubled experiment with paper money. At one point, an entertainments committee running a camp restaurant and shop issued notes backed 100 percent by food bought from prisoners. The food was prepared, and then marketed back to them for notes or cigarettes. All was well until bombing interrupted the restaurant's operation, staple food supplies grew so short that soldiers no longer "converted" their own food into paper at the restaurant-shop-banking hybrid, and luxury foods that people no longer wanted piled up as reserves. People eschewed paper, the notes lost value, and "the cigarette re-established itself" as currency. It subsequently survived a price fixing attempt: when senior officers tried to

3 Radford, supra note 1, at 190-91.

4 Id. at 192-93, 195-96. Radford apparently intended his case study to certify the primacy of exchange as the essential dynamic of the market, remarking that a market had arisen despite the absence of labor and production and was thus "difficult to reconcile" with the labor theory of value. $I d$. at 192-93. His textbook demonstration of the quantity theory included attention to the elasticity of demand for cigarettes and the effect of expectations. Id. at 195. 
dictate paper money prices by holding them steady at the shop, trade on a "black market" in cigarettes undermined their efforts. ${ }^{5}$

The POW case study operated on a basic premise: money was found, not made. Cigarettes literally dropped into the story, delivered by post and truck of the British Red Cross Society. They were pure commodities, free even from the production process; the prisoners who received them in rough equality had no link to the labor that had created them in an outside world. As pure commodities, cigarettes offered an obvious and expedient tool for exchange. And exchange naturally occurred because, as Radford put it, human affairs "are essentially practical matters." Prisoners might be suspended between exigency and excess, stranded above subsistence and below luxury, but they could still improve their lot. Because a prisoner could exchange goods and services, Radford wrote, "his standard of material comfort is considerably enhanced." When it was found to allow exchange between prisoners, the cigarette began to circulate. Money was an outcome, in other words, a use object deployed in the normal and unplanned course of human interaction. ${ }^{6}$

That character of money was important to its history. Money was a result, a product, a commodity used "as a response to the immediate needs and circumstances" of men looking only to make things a bit better. Events in the POW camp played out to confirm that money carried that basic identity. The threats and problems that destabilized the free market established by the prisoners and their cigarette money all came from interventions to that logic. Fluctuations in the cigarette supply, especially the sudden abundances caused by generous injections of cigarette money, were most disruptive. Then there were the dangers of debasement, the problems of paper money, and the ineffectuality of price controls; they also upset the effective operation of exchange to distribute goods and services in line with the prisoners' preferences.

The imperative of the account becomes obvious. The market and money were linked at a very basic level. They gave rise to one another: exchange produced money and money allowed exchange. And if that were true, their characters were connected as well. Just as money functioned best when it was a commodity that was constant in quantity, free from debasements and price controls, and independent of the collective contrivances supporting paper notes, so too the market worked best when left free of attempts at engineering. The setting drove home the message with patriotic overtones

5 Id. at 195, 196-200.

6 Id. at 189 . 
- after all, these were our boys using American enterprise and simple wholesome cigarettes to create a free market in the face of Nazi authority.

Deep into the confusions of the twenty-first century, the clean lines of Radford's paradigmatic account beckon with an almost irresistible grace. Witness their appeal as a teaching tool. They promise a foundational logic, a touchstone, a compass that is arguably even more important in these more complicated days. They capture a powerful intuition about money's origins and its character that continues to anchor assumptions about the market. Most of that history is imagined and modeled rather than mapped, but it is all the more powerful for that. ${ }^{7}$ Before stepping back to wonder about the stunning incongruity at the heart of Radford's story - a free market among prisoners-of-war? - we should consider the history and theory so plausibly attributed to money in more normal times.

It starts with the commonsense of a silver penny. Coin is the archetypical commodity money. The monies of the medieval world - it seems obvious, undeniable - were disks of precious metal, slivers of durable value that circulated, commodities in traveling form. There is even a genesis story that explains their origin. It imagines the Dark Ages as a sort of soup. Exchange was a murky broth of barter in which people traded all sorts of objects among themselves - grain, gold, cows and hides, promises, services, fish, and salt. From that fluid mix, metal rose gradually like fat to the surface, becoming a favored medium and marker of value as it passed endlessly from hand to hand. Its brokers were the actors imagined by Marx and Menger, buyers and sellers converging upon pieces of precious metal to mediate each transaction and, ultimately, to create prices in a common medium. The story arcs from that foundation in a simple monetary world through centuries in which people transferred value tangibly between themselves in direct exchange. It comes to ground in the age of the gold standard, understood as an order that institutionalized the anchor naturally provided by metal. ${ }^{8}$

The popular intuition and its imagined history can be modeled to capture the logic behind them. There must, after all, be a mechanism that would

7 For a review of the apocryphal histories often attributed to money, see for example L. Randall Wray, Alternative Approaches to Money, 11 THEORETICAL INQUIRIES L. 29 (2010).

81 Karl MarX, Capital: A CritiQue of Political Economy 162-63 (Ben Fowkes trans., Penguin Books 1976) (1867); CARL MENGER, PRINCIPLES OF ECONOMICS 263 (James Dingwall \& Bert F. Hoselitz trans., N.Y. Univ. Press 1981) (1871). Angela Redish describes the popular account of the gold standard as providing a nominal anchor for price. See ANGELA REDISH, BIMETALLISM: AN ECONOMIC AND HISTORICAL ANALYSIS 3 (2000). 
produce commodity money absent the existence of the British Red Cross Service. Once theorized, the way a "commodity money" works seems all the more self-evident, offering a persuasive baseline for an approach to the market. The intuition becomes academic and enters the domain of knowledge.

As macroeconomists articulate it, an "ideal commodity money" creates money with stable value by tying prices for commodities in coin to prices for commodities in metal. Linking the stock of coin to the supply of a metal prevents the quantity of money from fluctuating independently of the market for that metal. The technique should stop the price hikes that would occur if a mint-master anxious to produce more simply issued twice as many coins with half the amount of metal in each (a ploy that obviously would only work until people figured it out and started charging twice as much in the new coins). Just as the arbitrary spikes in cigarette supply had disturbed the market in the POW camp, so the increase would disrupt stable prices in a market using coin. ${ }^{9}$

A government can create such a system by identifying the metal content of each coin (for example, ounces of silver/penny), and converting metal to coin at the demand of users. Coin is easier to use than raw metal, so people will often prefer to take it, selling their goods at a lower price in coined metal than they would demand in silver bullion. Users will choose to have coin rather than silver whenever the value of coin exceeds the value of the silver in the coin - in other words, whenever prices in coin stay below the level they would be if stated in amounts of metal, given the amount of metal per coin. When those prices are equal, the holder of coin can buy goods either at the "world price" of goods in silver (oz silver/gd), or at the price of goods in coin (oz silver/gd // oz silver/penny), which would come to the same thing. ${ }^{10}$

9 If, for some reason, the mint-master wanted to have less coin, he could of course double the amount of metal content in each unit and prices would drop. The effect would be the same as when stressed soldiers smoked their cigarette money and so took it out of circulation.

10 "An ideal commodity money system is designed to equate the price level to a relative price of metal for consumption goods, and by making stocks of coins endogenous, to prevent effects on the price level coming from exogenous fluctuations in the quantities of coins." Thomas J. Sargent \& Francois R. Velde, The Big Problem of Small Change 11 (2d ed. 2002); see also id. at 22 ("An ideal commodity money makes the price level proportional to [oz silver/gd - the world price in silver], where the factor of proportionality is . . the number of coins of [a certain type] per ounce of silver."); id. at 12 (noting that the standard formula adopted in the nineteenth century made token coin "costless to produce upon demand," which 
The system set up by the government creates a device that will equilibrate the amount of coin in circulation. People will mint or melt coin depending on how much they value money's services compared to the other things they might do with the metal that is in it, including paying or charging for other commodities. When prices in coin rise above the level at which prices in coin and in metal are equal (i.e., the value of coin falls), users would rather have the silver in the coin, which they can use to buy more goods or for other purposes. Coin will be melted for its silver content. As coin leaves circulation, prices in coin will fall until coin and silver have the same relative value. Conversely, when prices in coin are below the point equal to the value-by-weight of coin, the value of coin will be higher than the metal it contains. People will go to the mint to get coin. That will raise the amount of coin in circulation, in turn raising prices in coin until they reach the point at which the value of coin equals the value-by-weight of coin (in other words, the value of the metal in the coin). Individuals considering their advantage in matters of exchange melt or mint precious metal in response, tying the total quantity of money and thus prices to the independent and shared supply of metal. ${ }^{11}$

The "ideal commodity money" model is, in itself, a kind of genesis story. Its dynamism turns on individuals who calculate the value of coin according to a "world price" for silver, the commodity at the heart of the system. Participants use that referent to determine the amount of coin in the system. They can pay for goods in either silver or coin, and choose between the two by comparing the world price of goods in silver to the price of goods in coin. Coin is effectively identified with the commodity; it is distinct only insofar as it imports convenience, measuring and regularizing the commodity. The public role is facilitative and administrative: the government mints silver into units, setting a starting point for subsequent action by individuals. Indeed, the system is self-calibrating, as opposed to centrally defined: the decentralized and rational actions of participants produce an equilibrium that is ultimately good for everyone.

The model of commodity money maps the market. That market is autonomous; there are no competing sovereigns. It is uniform and aggregative; individuals need never collide with a concerted public. There are therefore no politics. Bipolar deals, the product of self-interested initiative doubled, drive the system. Government is a freely available coordinating

would assumedly supplement larger denominations tied to metal); see also REDISH, supra note 8 , at 3 .

11 See, e.g., SARGENT \& VELDE, supra note 10, at 9-12. 
device, a technical service that provides the platform for individuated action at no cost. Value is a purely internal matter, one determined by the natural forces of supply and demand.

The conditions of this model of commodity money are at once internally consistent and strikingly abstract. They suggest that we take a second look at where we started. After all, Radford's account was about the real world. But there is a problem with the paradise presented there and the problem is critical. That "brand new society" - with its cigarette currency and its pristine market - was a POW camp.

Recognizing that fact subverts the meaning of the microcosm. The condition for the function of its market and its money was a situation in which governance and all the functions of the collective had been externalized and determined by an alien power. Note that centralized authority was not absent; rather, it was omnipresent, fixed, and definitive. The structure that determined Radford's camp thus established as premises precisely those issues of relative value that are negotiated collectively when a community of users itself creates a currency — and, for that matter, a market. Those issues range from the profound to the apparently mundane. Each connects a society's constitution, as a dynamic of people interacting, to its money, as the mode they use together and as individuals to mark and transfer value.

Most basically, each community defines and supports the conditions that invite "exchange" at all, rather than theft, autarchic subsistence, familial sharing, or charity. And when it acts to define and support those conditions, each community decides what flow of value it should recognize or disallow as well as who should contribute materially to the effort to support exchange and whether it should be in labor, supplies and services, or a currency that will transfer value to the collective. The prisoners had no need to create and pay for the conditions that premised their everyday exchanges, from the guards to the way they were fed, because others had conclusively done so for them.

Similarly, each community determines the way people within it will produce and claim resources relative to the larger group. And when it acts to determine that, each community draws territories of obligation and exclusivity that define how many resources people should share, use, or hoard, and for how long, including claims of ownership and inheritance, duties of support, and limits to reciprocity. It then joins those determinations to the channels that it recognizes to represent and carry resources, whether in kind, in service, or in tokens. Just as they had no say in creating the conditions for exchange, the prisoners had no involvement in determining the reach of each prisoner over resources relative to their group, there in 
a context that dictated the quantum of sustenance and shelter, removed freedom, and made labor extraneous.

At a more mundane level, each community engineers a unit to carry value when it makes a money. When it undertakes that project, it determines what to use as money as well as how to pay for it. No commodity is naturally suited to serve as money in the real world, simply suggesting itself across the myriad and decentralized deals that people make. Nor does the selection and management of money come free. Rather, the project of creating money and distributing its costs is negotiated collectively. Here again, the prisoners were not the agents that the economists have assumed. Cigarettes, standardized in size and quantity and free of charge, arrived from the Red Cross for each prisoner. That character set them apart from other supplies: food varied more in kind and shelf-life, clothing came in different sizes, and toiletries (of unspecified types) apparently could not be traded under camp rules. According to Radford's description, cigarettes may also have been the only item that German guards reliably accepted as bribes, giving them unique appeal. In the end, outsiders effectively customized a currency for the POWs and bore its costs. ${ }^{12}$

That money turned out to be artificially apt for the role, a last difference from a world in which governance has not been ordained in advance. The prisoners traded a highly compressed range of goods and services. Cigarette money mattered only there, not for breadth of values encountered in the world beyond the walls, including compensation for work, everyday expenses, and the outlays that buy land, homes, or labor. In the circumstances of the camp, as in the model of commodity money, an imaginary unit could reach as far as anyone's desire. In real communities, however, how far money penetrates - what transactions it irrigates and where it leaves people to other means, promises, and dependencies - depends on matters as simple as what denominations exist and whether they can be divided. Those apparent technicalities - the packages in which value flow — reflect, promote, and sometimes transform the priorities configured by a community into economic exchange.

The incongruity of modeling a free market on the operation of a POW camp reopens the questions that model meant to put to rest. Just as much, it puts at issue the money identified there, an artificial commodity unconnected to the community and the way it configured the labor, survival, luxury, and basic relations of its members. A mode of analysis is at stake. Individual preferences are supposed to be expressed and ordered by market exchange.

12 See Radford, supra note 1, at 190, 192, 197, 199. 
That assumes a medium independent of the matters it measures. If, however, communities make their money rather than find it, their decisions configuring value affect the transfers that money will measure. Insofar as money itself represents an intricate arrangement of claim and obligation, then the market is also a collective orchestration rather than the aggregate of individual choices. Far from settling our approach to the market and its money, the Radford article problematizes them.

How do communities that are self-governing make money and the markets it constitutes? How do their decisions about how to mark and transfer material value connect to the way they define "exchange" and other forms of moving resources? How do those decisions connect to the resources people claim or contribute relative to the group? How do people create the transfer of value in a way commonly accepted in the first place, who pays for it, and how does that affect the way material value travels through a society? How does the very size of money's packaging determine the use that people can make with it, divide the people who are exchanging it, or distribute them into other strategies to make and move value? How, in the end, do the ways we "make" money affect the way we relate people and things?

$$
* * *
$$

One way to begin exploring the knot that binds money and market together is to reconsider coin, the archetype of commodity monies. Assuming that money is made, not found, invites us to reread the history of the silver penny. Medieval money was minted of valuable metal and that content was important to the way people thought about coin and used it. But instead of treating the commodity as the end of the money story, perhaps we should treat it as the beginning. We should ask how a commodity came to be configured as money, at the outset and over the long years in which silver and gold coin circulated through early England.

That query opens up a whole drama, one that exposes the very interactions left out of Radford's story. The medieval world struggled for centuries to make money out of commodities. Selecting a commodity material, competing for its supply, minting it into coin, maintaining that coin in circulation, structuring denominations, securing small change for everyday use, protecting money from fraud - all were immense challenges. Invisible if we assume that money is simply the commodity it contains, the constant effort brought individuals into collective relation; money was an alloy of individual action and public orchestration from the beginning.

We may start where the convention does, with silver or gold carried to the surface by the hands that exchanged it, making it a common medium 
subsequently confirmed as money when it was coined. In fact, the story goes the other way around. The years imagined as the Dark Ages were far from fluid. Across a fractured and difficult landscape, people bartered with local and dispersed means that further fragmented the spaces of exchange. Metal emerged from that obscurity only when a political act - one that packaged metal as coin - selected it to perform an essential role. When they made it into money, the people creating coin anointed a metal as the common medium of their community, liquefying it quite literally. In turn, silver and gold (or more precisely, sometimes silver and sometimes gold) gained the currency required to state common prices; the chosen metal became the universal equivalent after, as opposed to before, it was incorporated into money. Money was not, then, an outcome, the confirmation that a commodity had come to dominate in marking value. It was an intervention that defined the commodity that would be used to mark value.

Innovated by a constitutional act, money persisted as a matter created by relating people to a larger community. The early English "made money" through arrangements that distributed the claims and obligations of individuals relative to the political world in which they lived. Coin became established as "money" when it gained critical capacities through those arrangements.

First, the Anglo-Saxon kings empowered coin when they used it to define the amounts they owed people within their power or claimed from them. When political authorities assessed payments or taxes in coin, they created it as a unit of account. ${ }^{13}$ As authorities used or accepted coin in satisfaction of obligation, second it became a mode of payment. ${ }^{14}$ Coin, available in the quantities produced at the sovereign's mints, became reliably valuable as a means of settling an obligation. At the same time, the actions of public authorities taxing and paying in coin made it more than a conduit that singly connected government to its contributors and creditors. Government in its

13 In the early Middle Ages, coins "counted" out an amount of weight in metal. Over time, the correspondence between the value of coins by count and the weight of coins in silver (or gold) declined. That correspondence was not necessary in order to create a system that marked value in regular ways, as the following centuries made clear. For the critical character of counting coins, even coins that had a corresponding weight in metal, see REDISH, supra note 8, at 5-6; ALBERT EDGAR Feavearyear, The Pound Sterling: A History of English Money 2 (E. Victor Morgan ed., 2 d ed. 1963); Nicholas J. Mayhew, From Regional to Central Minting 1158-1464, in A New History OF THE Royal Mint 83, 97 (C.E. Challis ed., 2d ed. 1992).

14 The same phenomenon created money as a "store of value" insofar as the production and withdrawal of coin created a predictable path for the money supply. 
many forms was the most common debtor, the only entity that might owe anyone. And government was also the most common creditor, the only entity everyone might owe. The tokens it took, unlike those preferred by any other actor, thus mattered to everybody. Third, the legitimacy that coin gained from that common demand began to travel when political authorities made it transferable. Insofar as they issued coin that was indistinguishable, one piece from another, and took it back the same way, people could exchange coin in the meantime without jeopardizing its ability to settle debts with the center. Coin thus gained currency as a unit of account, mode of payment, and medium of exchange. People could use it among themselves to measure, store, and transfer value.

Engineered by the relations that allowed it to function so distinctively as "money," the capacities that coin acquired set it apart from a commodity. Early minting systems made silver into coin, and coin into money, by harnessing the demand for that liquidity. At first, sovereigns likely coerced individual participation in the project of making money by requiring payment in a chosen currency of newly minted coin. Eventually, they moved to a less heavy-handed approach: they minted coin for a price. People accepted that offer when they valued coin more than the raw metal that they held. That was often the case because coin had been blessed with the benefit of liquidity. Coin offered a way to pay the government and accepted there, coin also became the medium that people could negotiate in more decentralized circles.

The model of commodity money requires readjustment to reflect the revised history. England's early minting system made money out of metal, a substance that had commodity value. But the whole enterprise was powered by an insight about the very value that set money apart from a commodity. That value - liquidity - was the centripetal force that brought government and people together to produce money. For reasons that varied across communities and centuries, both sought the positive capacity it offered, a capacity they could engineer jointly when people contributed to the government and the government used its unique authority to create a circulating medium in return. The amount that people paid for money represented the value they placed on the liquidity it offered in contrast to the value of the metal they would otherwise hold. The evidence for the degree to which people valued liquidity - the price they paid for it at different moments - is elided in the model of the ideal commodity money: skipping over all the interactions that make money real, the model casts making money as a matter merely of minting, and minting itself as a free transmutation of metal rather than as an act locating liquidity as something that comes at common cost. 
In fact, insofar as money was a commodity given its metal content, that commodity character constantly threatened to undermine the liquidity that money offered. The problem occurred because a commodity in the real world, as opposed to its imagined alternative, had value as a substance that was at odds with the value that a money made of it (i.e., the substance blessed with the added public virtue of liquidity) had to carry in order to be minted, maintained in the country, and used effectively for exchange. In other words, the commodity content of coin brought problems in many ways counterproductive to coin's success as a medium. It drove sovereigns to compete among themselves for the raw stuff of coin by hiking the price of bullion. It imposed limits to durability that upset the correspondence between a coin's asserted value and its value after use. It linked the proportional value of coin's content to the projected value of coin's liquidity, no matter how much greater the liquidity provided by small coins might be than the liquidity provided by larger ones. The content of coin introduced those problems on top of and independent of the fact, better known, that it tied coin to a commodity that could erratically increase or decrease because of changes in physical supply unconnected to economic activity and the demand for money.

English sovereigns responded with reforms that supported and expanded liquidity by moving coin farther away from the commodity weight that had originally given money its measure. The Crown regularly ordered its mints to reduce the amount of metal in each unit of account, driving coin away from its starting point as a particular weight of metal that obtained a particular value in the commodity market. The tendency to dilute the commodity content of money was chronic and significant over the centuries; Angela Redish goes so far as to call the trend "inherent" to a system that bases money on a commodity. ${ }^{15}$

Medieval coin was not, then, a "commodity money" as convention imagines it. Neither silver nor gold offered a commodity equivalent that became institutionalized as money; rather, their selection beforehand as the content for coin made them subsequently the touchstone for prices. Nor, once incorporated into coin, did silver and gold simply enter circulation as money. Rather, coin became money because of the unique channel it created between authorities and laypersons, and among people more generally. Nor did silver and gold, even as amounts within coin, offer a static base for value. They were part of a much more intriguing alchemy, catalysts for the

15 REDISH, supra note 8, at 4. 
creation of liquidity that was concerted by political authority among the participants who would use coin as currency.

The next pages explore the political innovations that produced early coin and the constitutional arrangements that allowed it to operate as money. When authorities paid people in certain units of account, imposed obligations using that measure, levied taxes in the measure's coined form, and allowed only that token to be transferred, they configured the way people related to the political community and others within it. At the same time, they set coin apart from the commodity it contained, endowing it with liquidity. The history here considers how medieval authorities built that reality into the system. "Free minting" relied on the demand for liquidity, the very quality that collective arrangements produced and that commodities lacked, to attract silver and gold to the mint. The system diverged from the ideal commodity model in ways that reflect the theory that shaped it: its structure created coins, but in a way that performed their provenance. Free minting exposed the political authorship of coins and it charged for them directly, constricting their outflow more than other systems. Free minting acted out, finally, the fragility at its heart. Even as its engineers relied on the valuable capacities that distinguished money from its content, they treated money as a simple commodity when they assumed that it could be based on static amounts of metal. That contradiction spun out one problem after another the haunting reminder that money and the commodity it contained were not the same thing. The struggle that resulted shaped the early English political economy.

Revising an approach to money against its medieval history does not simply flip the myth of its production, introducing a public aspect where private action prevailed before. It situates money in a multilateral world, one constituted by far more than a bipolar transaction, no matter how many times multiplied. In the end, the approach redefines money and the value it carries as a constitutional project that links the government to its participants. As its medium, money created the code of value in the medieval political economy.

\section{The Dawn of Desire: Producing LiQuidity From a Commodity}

The middle of the first millennium in England was a parochial place in more ways than one. It was a periphery of space and time that was rude rather than exotic, an island that was not so much undiscovered as left in the wake of an imperial retreat. Those "dark ages" were no primal beginning. The communities that emerged in the western provinces after the decline of the 
Roman Empire and before the rise of European medieval society inherited the legacies of the earlier order, including the odd imperial coin and fading patterns of exchange. More to the point, there may be no primal beginning at all. The origin of money is not a moment, queued into a sequence of development; it is a desire, wrapped into the interaction of a group. The compass that orients "money" as we the use the word picks out the effort to capture value and convey it. In that sense we can begin anywhere.

But though it may have been parochial, England in the middle of the first millennium is not an entirely arbitrary place to start. Driven by a concern to understand Western terminologies of value, the history here queries the money that came to dominate the English world. That effort gains traction by tracing the medium's changing form. Moreover, the currencies that had plied the ancient world and carried value across the Empire collapsed in England more completely than anywhere else in Europe. As they vanished, they created conditions closest to those that the story of commodity money imagines as its setting - primitive people, barter, weak and shifting senses of "state." And even there, looking towards its early medieval dawn, money appears more parts political invention than social occurrence or convention. Coin did not confirm silver or gold as universal equivalents, simply capturing the world prices (or the rather more local version of world prices) they stated. Rather, coin created silver (and only much later gold) as a universal equivalent (at least, again, in a very local sense) by incorporating it into money. ${ }^{16}$

Gold, not silver, dominated the late Roman Empire as the metal chosen to make up its money. The solidus, 24 carats of gold, supplied the currency used by the government to pay its army - "soldiers" because of the coin they received. The solidus paid as well for the court and civil service and the system of imperial communication. Acting with solidi, the Empire also assumed the cost of buying and distributing food to parts of the urban population in Rome and Constantinople. Landowners and others in the senatorial class bought and sold, collected revenues, and assessed rents, again in gold solidi. ${ }^{17}$

16 It would assume too much global exchange to look for "world" prices in silver. See infra note 84 . A realistic version of the spontaneous commodity money model would assume that the commodity prices stated in a common medium would emerge over a smaller but significant geographic region - southeast England, for example. The opposing argument is that goods would not gain a common commodity (e.g., silver) price tag until a political unit had selected that commodity as the relevant marker.

17 Peter Spufford, Money and Its Use in Medieval Europe 7-8 (1988). 
A copper coin called the nummus circulated as the small change to the larger and more aristocratic denomination. There were 7200 copper nummi to a single gold solidus during the fifth century, rising at times to twice that number. These were the coins used in the everyday exchange of ordinary people: when one solidus bought 200 pounds of pork, 36 nummi got you a pound. Silver coin was surprisingly scant; the Romans toyed with an intermediary silver denomination worth one gold carat, but, despite the convenience we might imagine it carried, they minted little of it. At the end of the fifth century, they had settled on larger copper coins to subdivide the solidus in Rome, Carthage, and Constantinople. ${ }^{18}$

By that time, however, the currency had already broken down in Britain. After the Roman army left and administrative connections ended, coin stopped flowing to the outpost. According to Peter Spufford, "within a generation, by about A.D. 435, coin ceased to be used there as a medium of exchange . . . although many survived as jewellery, or were used for gifts or for compensation." ${ }^{19}$ Coin contracted more slowly across the rest of Europe. In those areas that had been the western provinces of the Empire, Gauls, Franks, and Visigoths took over the mints left by the Romans. They continued issuing coins - at first in the names of the emperors, spending and taxing in it, and even receiving political subsidies from Rome. The copper coinage was drying up, however, a slow desiccation that Spufford reads as reflecting the decline of urban life. The new rulers turned for a period to silver coin, at least for purposes of north/south trade. But by the second half of the sixth century, silver "siliquae" traced narrower and narrower routes, up the Rhine and into territory that had been a barbarian frontier. Within the next few decades, silver coin stopped being struck and gold money began to shrink.

Gold dropped out of commercial use as the tax system inherited from Rome fell apart. According to Gregory, Bishop of Tours from 573 to 594, the Frankish kings were hoarding gold, seizing it as treasure, dispensing it as prestigious gifts, and making political bargains with it. But they no longer used it for paying soldiers or civil servants, for maintaining a state infrastructure, or for making the "bulk purchases" of an Empire. "Without state expenditure the gold could not get back into the hands of the tax-payers," writes Spufford. "It ceased to be recycled through the economy and was fossilized in great royal hoards." The loss of liquidity, currency,

18 Id. at 8-9. A smaller gold coin, the "tremissis" and later "trientes," also circulated. Id. at 8-9, 19.

19 SPUFFORD, supra note 17; Ian Stewart, The English and Norman Mints, c. 600-1158, in A New History OF THE Royal Mint, supra note 13, at 1, 3-4. 
and monetary movement comes across as the constant in another metaphor: "The pages of Gregory of Tour," emphasizes Spufford, "drip with blood and gold, but it was gold not in circulation and use, but clotted and hoarded."20

Gregory's account of the Franks suggests the way gold money came to a stop more generally in northern Europe. Amounts in circulation had been dropping since the end of the fourth century, lost to hoarding or drained eastwards in trade. By the early seventh century, rulers were paying for military support in land; rents and other payments increasingly took shape in kind. ${ }^{21}$ Some long-distance trade continued in coin, but an increasing amount occurred through relations of "gift-exchange" that operated without money as a means of exchange. The unit of account set by the gold solidus outlasted the existence of the coin. Even here, however, the measure came to mean a particular weight rather than a denomination; pieces of gold of the appropriate weight were substituted for coin in caches that were dedicated to gift or funereal purposes. The solidus, in other words, assumed a commodity identity precisely when it failed as a currency. By the eighth century, the hoards of gold had been dissipated; Europeans had started making coins again, but they would turn to silver, now at locations as scattered as the claims of political authority across the European landscape. ${ }^{22}$

In "Primitive Money in Primitive Europe," Carlo Cipolla evokes something like the low-water mark of European money, the period most parched of liquidity. He describes the erratic occurrence of metal coin, both old and new, in early Europe. Coin was exchanged as a commodity, and the amount of metal it contained acted as a standard of measure. That character, however, did little to enable it as money in any meaningful way. The situation would have been especially extreme in England of the fifth and sixth centuries, where the end to money was even more absolute.

Cipolla paints an economic terrain fragmented by distance and disease, local networks and limited patterns of activity. A diversity of deals for food, labor, agricultural goods, land, coin, and loyalty made up a subsistence for many people. Records capture the heterogeneity of stuff that functioned as media of exchange. Many obligations were fixed in kind: peasants and other subordinates often owed their lords in grain, eggs, wine, cloths, and spices, as well as service. Other obligations created options for payment:

20 SPUFFORD, supra note 17, at 14-16. For the decline of gold as a means of exchange more generally across western Europe, see $i d$. at 14-22.

21 SPUFFORD, supra note 17, at 16, 55.

22 Id. at 15-18, 22. As Spufford details, while gold lost its "fiscal, rental, and commercial functions," it was still used as compensation for death or injury, certain fines, and wife-purchase. Id. at 17-18. 
a debt could be settled in coin or in a specified commodity. A shave, as Cipolla recounts the deal offered by an early Italian barber, could be had for either a silver penny or a sextarius of grain. Still other obligations were stated in coin, though again and again, people might pay them off in another commodity or a mix of commodities - livestock, cloth, grain that amounted to the same value. ${ }^{23}$

Coin could change hands in any such deal; indeed it appears regularly as part of a payoff. "The general impression is that any commodity was considered a potential means of exchange, and coins were considered just like any other commodity, one among hundreds of possible means of exchange, sometimes particularly desired and sometimes not." That practice, however, did not make coin dominate as "money." As a measure, coin referred to a weight of metal only, and coins that still circulated remained one way of fulfilling that standard, objects valued by their content and passed between people on that basis. In the view of many economic historians, the trade of mid-millennial Europe amounted to barter - it was varied and constant, just as later theorists might imagine. ${ }^{24}$ But it was not, in fact, spontaneously generative of a money supply.

On the one hand, coin was scant and its transportation dangerous; markets were scattered thinly across a landscape that was difficult to travel. The conditions suggest that coin would have been sporadically available, appearing in some villages and completely absent in others. Great disparities in wealth would have exacerbated the unbalanced distribution of coin, allowing some to hoard a supply while peasants and laborers rarely encountered a piece of silver or gold. ${ }^{25}$

If the supply of coin was erratic, demand for it was also tenuous. The great multiplicity of commodities used to settle obligations lessened the need for coin out of all the candidates available. Most people remained in basic or subsistence production; the exchange they made with their neighbors took familiar patterns and did not need coin to float. In fact, insofar as early market conditions delivered many goods erratically, participants may have

23 Carlo M. Cipolla, Money, Prices, and Civilization in the Mediterranean World, FifTH to SEventeenth CENTURY 3-4 (1967); see also SPUfFord, supra note 17 , at $17-18,22,35$.

24 Cipolla, supra note 23, at 7; see also SPUFFORD, supra note 17, at 17-18; GLYN Davies, A History of Money: From Ancient Times to the Present Day 169 (3d ed. 2002). For England in particular, see Stewart, supra note 19, at 3-4; Philip Grierson \& Mark Blackburn, Medieval European Coinage: With a CATAlogue of THE Coins IN THE FitzWilliam Museum 156 (1986).

25 Cipolla, supra note 23, at 9-10. 
preferred those goods to coin; they could be more easily passed on, like essentials in wartime. Those with thin margins of wealth would have been especially wary of taking a commodity like coin that offered few advantages in everyday life. Only the merchants who did not have barter networks used coin, which, Cipolla speculates, would account for the survival of large gold coin after the demise of everyday coin in silver and copper. ${ }^{26}$

Against those conditions, as opposed to the ones later economists would imagine, no one medium emerged. No currency became more and more common, increasingly to characterize the many exchanges people made with one another. Units denominated in gold retained a claim as a measure of value but that stature drew from tradition, itself a residue of earlier public projects, more than practice. ${ }^{27}$ Gold units offered a standard of weight but not a money, and it is hard to imagine how - in the fractured world of in-kind trade, sometime supply of metal, and limited demand - it could have been otherwise. In England, notes the chronicler of its early coinage, the dearth of coin disabled it from playing "a meaningful part in currency for any purpose" before the seventh century when sporadic issues began for non-commercial purposes - ceremonial burials, notional payments, and ornamental use. ${ }^{28}$ Without the assistance of spontaneous generation, in any case, events were unrolling to change the English economic landscape.

The history of the penny, writes Alfred Feavearyear, should start with "the coins struck by Offa." 29 That currency presented a silver money to England: as Offa's pennies washed across the countryside, they clinched the rupture with ancient practices of coinage. The innovation of silver pennies had actually occurred some decades earlier along England's southern coast, in commercial kingdoms that traded with their counterparts across the North Sea. And there, gold had been tangibly demonetarized. Frisian communities minted the precious metal in the sixth century, but gold coins had become "more in the nature of amulets" than currency. ${ }^{30}$ In the next century, Frisians

26 Id. at 6, 9-12.

27 Id. at 4-7. Note that to say that gold was not acting as a universal equivalent a money - is not to say that it had no value as a commodity. The gold solidus continued to figure in records; in practice it referred to the smaller denomination of tremisses or trientes, themselves struck in small quantities and inferior quality across Gaul, Frisia, the Visigoth kingdom, the Frankish territory, and in seventh-century England. See SPUFFORD, supra note 17, at 19.

28 Stewart, supra note 19, at 4-5, 11-12.

29 FEAVEARYEAR, supra note 13 , at 7.

30 SPUFFORD, supra note 17, at 19. Some scholarship posits a somewhat more significant, if temporary, role for a revived gold coinage in the seventh century. See DAVIES, supra note 24, at 119-23. 
and their Frankish neighbors began to strike silver in the same dies, modeling them closely on the earlier gold trientes and literally displacing that coin. Silver "denarii" became the common currency of the coasts, produced by the fragile centers of authority that lay along them. ${ }^{31}$ As their power ebbed during the eighth century, the coinage produced by those communities contracted not however before Offa and the Anglo-Saxon leaders who began reunifying England recognized the potential of that silver stream to irrigate their rule.

Their aspiration to create liquidity was tied tightly to their political ambitions. Emerging from a scramble of competing lords, Offa extended his rule south and east in the last half of the eighth century. And he nourished the effort with money - for soldiers, supporters, supplies, and goods. ${ }^{32}$ One estimate suggests that Offa put 6.7 million pennies into circulation. ${ }^{33}$ He patterned his penny on the larger, thinner denarius minted by Pepin and Charlemagne, itself modeled on Arab coins that had arrived in Spain — the history of money in the Mediterranean and the eastern world had followed a different course from that in western Europe, each twist shaped by its own politics. ${ }^{34}$ On the same principle that money and political authority inform each other, Offa's coins set a new standard for quality, uniformity, and precision as he consolidated his territory. Together with the denarii (soon called "deniers") of Charlemagne, the English coin took hold like a new monetary principle: the penny would dominate the European world for the next 500 years. ${ }^{35}$

31 See SPUFFORD, supra note 17, at 23-24, 27-32; Stewart, supra note 19, at 4-5, 11-13. The first English pennies were called "sceattas." Together with the Frisian pennies, they were much more abundant than Frankish coins. SPUFFORD, supra note 17, at 28-29; see also Stewart, supra note 19, at 4-5. For speculation on the political organization of the Frisian and Frankish communities responsible for the coinages, see SPUFFORD, supra note 17, at 27-30. For commentary on the sources of silver, see $i d$. at 30-31. While Spufford assumes that a changing balance of payments brought silver to England, significant supplies of the metal may have existed in England long before being used for coin. That possibility is consistent with the understanding that the metal did not act as money until given that form by political authority. For a similar delay in Greece, see $i d$. at 36-37.

32 For the argument that Offa innovated the broad penny relatively early in his reign, see Derek S. Chick, Towards a Chronology for Offa's Coinage: An Interim Study, 3 YORKSHIRE NUMISMATIST 47 (1997). He may also have copied the broad penny from his Kentish rivals, but been the first to establish the coin in the quantity and quality that made it revolutionary. See DAVIES, supra note 24, at 124-28.

33 D.M. Metcalf, The Prosperity of North-Western Europe in the Eighth and Ninth Centuries, 20 ECON. HIST. REV. (2d ser.) 344 (1967); see also commentary in SPUFFORD, supra note 17 , at 30 n.3.

34 SPUFFORD, supra note 17, at 35-40.

35 Stewart credits Offa with issuing the first broad pennies, although an earlier view identifies rival Anglo-Saxon rulers. See Stewart, supra note 19, at 13-14.; SPUFFORD, 
At the same time, the penny effectively appointed silver, the commodity it contained, as the "universal equivalent." Embedded in the measure of coin is a clue to how its history unfolded. The barleycorn, according to Pamela Nightingale, was the basis for the system of weights used by the Anglo-Saxons from the earliest days of their era. Graves in sixth-century Kent include pounds founded on the weight of those grains, some 5,760 of which, at .0637 grams/grain, made up a total of about 367 grams. That brought an indigenous measure, the barleycorn, into correspondence with a Roman one, the pound; Scandinavian and Byzantine influences would cut the weight by shifting units — oras, ounces, mancuses, and marks — across the following centuries. Scholars of early coin trace the flow, arguing that it limns the waves of economic activity and political domination that surged and collided across England, the continent, and the wider region. ${ }^{36}$

Lost in that erudite debate is a simpler point: the barleycorn and the measure it offered. Anglo-Saxon coin began from an agricultural measure, not an abstract amount of silver. Explanations of free minting usually offer that anachronism - a gram, or an ounce - as the unit for a "world price" we might imagine for a good in metal. From there, they move to identifying the number of coins that could have been produced from that amount of metal, assuming a certain amount per coin. Given the world price for a good in metal and the information about how much metal is in a coin, the price offered by a mint for coin becomes meaningful: people holding bullion would know whether it will be worth it to bring in bullion to get coin, relative to the world price for a good in metal. ${ }^{37}$ The structure of explanation subtly invites the familiar intuition: just as the world price in an abstract amount of metal serves as a reference point in the explanation, it furnishes a reference point in the creation of coin.

The barleycorn suggests a different sequence. It too offers an initial weight for coin in metal. But the barleycorn invites us to think of the mint authorities offering coin as heavy as a certain number of kernels to those bringing in metal. And it makes almost obvious the next step: the

supra note 17, at 41 n.6 (flagging alternative arguments). On the tie between coinage and centralizing authority under both Offa and Charlemagne, see Stewart, supra note 19, at 13-14, 20; SPUFFORD, supra note 17, at 40-44, 99-100. For the dominance of the penny, see DAVIES, supra note 24, at 126-27; SPUFFORD, supra note 17, at 27.

36 See, e.g., Pamela Nightingale, The Evolution of Weight-Standards and the Creation of New Monetary and Commercial Links in Northern Europe from the Tenth Century to the Twelfth Century, in TRADE, MONEY, AND POWER IN MEDIEVAL ENGLAND, selection IV, 195-209 (2007).

37 See, e.g., SARGENT \& VELDE supra note 10, at 18-21. 
mint authorities will take every tenth coin, or every fifteenth coin, or every twentieth, as their fee - a worthwhile charge for creating a token that will be so much more current than the metal that is in it. And those steps lead to a last. The amount of metal in the newly minted coins - those received back by the person bringing in bullion and those kept by the mint officials together - gains a particular relevance. It represents the raw material of a certain number of coins, independent of any liquidity. If coin should ever lose so much of its value as money that more coins than these are necessary to buy what people would trade for the metal, then people may as well melt their barleycorn coins and use the raw material instead. In this sequence, bullion becomes a marker of value - one that is related to the amount of metal in coin - but not one that predates it. The barleycorn thus reorients the story of coin, now around a measure - the basis for a unit of account - that was organic to everyday life rather than an abstraction derived from worldly exchange and the prices it hypothetically produced.

The Anglo-Saxon method of producing coin is just as suggestive as the measure they used. Early rulers relied on coin to finance their rule; they assessed taxes in it and demanded it as a mode of payment. That political imperative structured coin's production - a condition that escapes economic accounts that neglect the way early coin actually became current.

The "renovatio monetae" — the way the early Anglo-Saxons institutionalized the making of money - at first appears mysterious. We know it operated to bring metal and old coin in for minting (or reminting) at regular intervals. Some rulers renewed their money every two or three years, others recoined every six or eight years. Scholars have also established that local mints proliferated: in the last quarter of the tenth century, they increased almost threefold (from 25 to 70 mints) to blanket the English countryside south of York and east of Chester. The process of renovatio monetae coincided as well with a whole succession of coin types. At most recoinings, it seems, minters melted down their earlier pieces and produced a new and distinctive coin. Ethelred II (978-1016) turned the portrait on his father's coin right instead of left and added a "Hand of Providence" on the reverse side. He changed the Hand design on one generation of coins after another before replacing it with a cross embedded with the letters CRUX. $\mathrm{He}$ and his successors then tinkered with the CRUX design, producing at least 23 different versions. Over a period of 150 years, Anglo-Saxon and early Norman rulers changed their coinage at least 53 times. ${ }^{38}$

38 Stewart, supra note 19 , at 49 . Stewart reconstructs the lineage of types from coins found in hoards. $I d$. at $49-55$. 
The Vikings buried coins of the renovatio monetae across northern Europe; clues to the early money and the way it moved out of England come from the earth with the pennies. Recoinings became more and more frequent over time; more than a decade passed before Edgar (959-975) renewed his money, while only a few years separated the coin types of later rulers. Coins also varied in weight and, under certain rulers, a deliberate pattern appears: the earliest coins of each type are heavier, and they get lighter over time. Despite that variation, early pennies apparently passed at a stable value; their worth evidently depended on a demand for them created by more than their intrinsic metal content. ${ }^{39}$ Finally, most of the hoards hidden in Anglo-Saxon territory in the late tenth and early eleventh centuries contain coins from only one minting; the remaining hoards include only a few pennies from an earlier type. Remintings must generally have wiped out all the coins of a previous series, reaching almost all of the money in circulation. ${ }^{40}$ Individuals motivated to replace money worn down or damaged would have renewed their pennies much less often: in a cache dating to the fifteenth century, when individuals were left to their own devices to recoin money, fully a quarter of the coins were more than a century old. ${ }^{41}$

In 1178, the author of an early treatise remarked on a dispensation made to taxpayers from certain counties: during the reign of Henry 1 (1100-1135), they had been allowed to pay their dues with coin of appropriate weight and fineness from any mint, since they had no moneyer of their own. Around that comment and other evidence, the clues left behind by the pennies of the renovatio monetae start to coalesce. Apparently, monarchs periodically required that taxes, gelds, and other payments be made in a new coin. That forced people to the mints; rulers authorized small operations to produce coin locally. Changing the design of coin made it easy to confirm that the coin was renewed, while the plethora of locations made the logistics possible. As the coin came in, the king levied a charge for minting: Spufford estimates that royal profits amounted to 25 percent of the metal minted on each occasion. The renovatio monetae was, in other words, a powerful mechanism for raising revenue..$^{42}$ It worked because monarchs forced people to use certain coin as a mode of payment.

The renovatio monetae reflected strong central authority and, in turn, helped finance that regime. The Anglo-Saxon monarchs evidently enforced

39 See SPUFFORD, supra note 17 , at 94.

40 Stewart, supra note 19, at 50-58; SPUFFORD, supra note 17, at 94.

41 Stewart, supra note 19, at 55-59; SPUFFORD, supra note 17, at 93 \& n.2, 94-95.

42 See generally Stewart, supra note 19, at 55-59; RICHARD FITZNIGEL, DiALOGUS DE SCACCARIO (1178), cited in id. at 59; see also SPUFFORD, supra note 17, at 93. 
royal levies effectively enough to pull off the required renewals. An early tenth-century law that "there shall run one coinage throughout the realm" further supported the mints by prohibiting the use of foreign coin. England's wool trade boomed during the period, so metal flowed to the mints. ${ }^{43}$ Until the mid-tenth century, many of the new coins went north as political tribute or levy to the Danes. The ability of Anglo-Saxon kings to control their own territory while contending with the terror to the north and paying out so much itself testifies to their power. Coining money made money for the state, which could then reinforce its rules. ${ }^{44}$

That politics promoted money as a means of exchange more broadly among laypersons. It prompted landowners who owed gelds to privilege the money that could pay them. Their demand made money more valuable to their tenants. Peasants who had been paying their rent in services and in kind began to pay a portion of it in coin. Political officials accepted coin that had changed hands in the countryside. Courts decreed that an offer of coin sufficed to pay off the obligations that private parties owed each other. Those endorsements allowed coin to travel as a medium of exchange. Only coin was privileged as a universally transferable medium in England until the eighteenth century. ${ }^{45}$

Larger mints in regular production along with smaller mints more sporadically active spread money across the countryside. While its quantity remained low by modern standards, coin seeped into the deals made by many more people in England and, for that matter, in Scandinavia. The Domesday Book, William I's survey of England's population and resources, "presents a picture of a society full of money, and money payments." It paints towns in which landlords charged and received money rents. Their tenants

431 ENGLISH HistoricAl DocumENTS 384 (Dorothy Whitelock ed., 1955), cited in SPUFFORD, supra note 17, at 87. Although existing scholarship does not address the possibility, the law may have applied to the new coins produced at each renovatio monetae.

44 SPUFFORD, supra note 17, at 90-91. For the recent argument that the Anglo-Saxon period was characterized by strong governance, see PATRICK WORMALD, THE MAKING OF ENGLISH LAW (1999). A consensus to that effect has prevailed among those considering monetary dimensions of English history. See, e.g., PAMELA Nightingale, "The King's Profit": Trends in English Mint and Monetary Policy in the Eleventh and Twelfth Centuries, in Trade, MONEY, AND POWER IN MEDIEvaL ENGLAND, supra note 36, at 61, 61-63, 70-71; SPUFFORD, supra note 17, at 92-94.

45 James Steven Rogers, The EARly History of the LaW of Bills and Notes: A STUDY OF THE ORIGINS OF ANGLO-AMERICAN COMMERCIAL LAW 170-93 (1995); J.K. Horsefield, The Beginnings of Paper Money in England, 117 J. EUR. ECON. HIST. 36 (1977). 
in turn sublet for money. Their neighbors in the country were also turning more and more to coin. The Domesday Book details the problems with cash payments, commenting on when coin should be weighed or counted and thus confirming that actual coin was passing in these transactions. The period marked "the real start of a money economy in western Europe," writes Peter Spufford about the revival of silver mining in Germany; his words capture the production and dissemination of silver pennies from England just as well. ${ }^{46}$

Over the next several centuries, minting rose and fell with the political tide: coin was the means that made defense possible, enabled the ambitious extension of authority, and consolidated a realm. Some of the highpoints are famous. William strengthened the coinage as he mapped the taxable capacity of England. The Domesday survey was, first and foremost, a financial blueprint; it promoted the trend towards the use of coin by valuing goods and services in cash. After a period of civil war, Henry II reasserted sovereignty - and wielded coin as a centralizing weapon. He shut down the scatter of provincial mints, demoting the barons and concentrating economic power in London. He converted feudal dues from military service to cash. That change shifted his nobility away from armed readiness and increased their dependence on the Crown's protection. In a related vein, Henry began building a professional army, paid with the new cash and controlled by that string. ${ }^{47}$

Other episodes are less well-known. The anarchy that preceded Henry II was acted out in coin: moneyers began blurring their products so that rivals for the Crown would not know which one had issued money for their opponents. Another measure during the same period was even more aggressive: several mints scored Stephen's portrait with heavy lines after he quarreled with the pope. Coin carried the propaganda from hand to hand as it traveled. ${ }^{48}$

Both high and low moments confirm the same conclusion. Liquidity was not something found, it was something created. A political act, money expressed the authority of sovereigns as they measured out pennies, required

46 See Spufford, supra note 17, at 87-90; Nicholas J. MAYhew, Sterling: The HISTORY OF A CURRENCY 3-5 (2000). The evaluation of the Domesday Book is from Mayhew, id. at 3; Spufford's evaluation is at SPUFFORD, supra note 17, at 77.

47 MAYHEW, supra note 46, at 3-5, 16-18; DAVIES, supra note 24, at 135-38, 140-42; Mayhew, supra note 13, at 83-86.

48 See DAVIES, supra note 24, at 140-41. See also MAYHEW, supra note 46, at 11-12, for more on the way that coinage during the twelfth-century civil war reflected the fracturing of sovereign power. 
them back from their subjects, and ordained their ability to be transferred. It engendered the power of sovereigns as it paid for arms, men, goods, and officials. More than that, pennies took political authority into the everyday affairs of laypersons; they calculated the strength and stability of the Crown every time they bought, sold, or saved.

Pennies conducted politics in another, less conspicuous way as well. They joined public and private in the very act of creation, connecting them by the intimate relationship that generated liquidity. In the Saxon and early Norman years, the renovatio monetae witnessed to the extent of royal control and suggests that coining was routinely coercive. The English revised their system in the twelfth century. The new system reduced the burdens placed on people required so frequently to remint their money at a cost. It carried forward, however, the insight that individuals sought liquidity just as (and indeed because) the government did. In fact, it made that insight central.

\section{Refining LiQuidity: Free Minting AND the Conversion of Silver to CoIn, AND CoIn to Money}

The Norman rulers of England inherited silver as the content of their coin. They refined that inheritance in order to convert bullion more effectively into money. The key to the system they created was not, however, the metal that provided the substance for coin. It was their system's ability to focus the common demand for liquidity - the capacity that set money apart from metal - into a productive force. They channeled that force through the "free minting" system to create coin, and then converted coin into money by using public power to privilege it as a medium. The free minting system suggested in its very structure the relations that animated it. It distinguished money as a matter that was politically authored and came at a direct cost to people. Moreover, free minting exposed a deep fragility in the theory that commodity value and liquidity value corresponded one to another. As the free minting system operated, it configured the larger political economy along those vectors.

The English began revising their approach to money in the middle of the twelfth century. The anarchy that marked much of Stephen's rule (1135-1154) had decimated both the coinage and the strongly centralized authority that produced it according to the method of renovatio monetae. Henry II did not attempt to resurrect coin renewals. He oriented his efforts instead around the resource that the Crown could promise those who cooperated. Liquidity was not only a demand that motivated sovereigns; it was also a capacity that people found helpful in everyday life, whether navigating 
personal dependencies, the burdens imposed by public authorities, or the opportunities that exchange in money opened to them. The approach that came to be called "free minting" - not because minting was free of charge but because it was freely available for a fee - traded on the fact that the resource of liquidity did not occur naturally. According to the approach, the Crown minted all raw metal or bullion brought to it, charging users a price for the privilege represented by coin. In return, the government ensured that the coin, once produced, would carry all the advantages of liquidity: it represented value that could be easily "told" or counted rather than weighed, could be transferred in payment of all debts, and would maintain its value because the supply and demand for it, still anchored on public taxes and spending, were ensured through government action. Free minting produced coin, in other words, and the privileges accorded coin turned it into money.

Recognizing the larger dynamic revises the account of commodity's creation in the real, as opposed to idealized, world. In order to produce coin, the English government authorized mints to convert silver into pennies at a fixed "mint price." (They would add more denominations in the next century. ${ }^{49}$ ) The mint price included charges for the production costs of coin and for "seigniorage," or taxes taken by the sovereign. Under the terms of the trade, users received less silver back from the mint than they brought in, but they received it in coin. The mint price thus specified the number of full-weight coins that would be returned for a given weight of silver. The public charge was taken, assumedly also in new coins, from the balance of the silver that had been brought in. The sum of the mint price and the public charge, known as the mint equivalent, represented the total number of coins that had been made from the bullion. ${ }^{50}$

Free minting turned on people's desire for liquidity because it was that demand that brought them to the mint, despite the charge for money imposed by the government. As long as the cut taken by the government was not too large relative to the value of coin and bullion, users made the trade willingly because of the advantage coin held over silver or gold. "Willingly" is of course a relative term, one that begs for context. At broad brush, taxes and

49 See DAVIES, supra note 24, at 144.

50 All three prices thus came as coins per amount of metal (e.g., pennies/oz silver). See REDISH, supra note 8, at 27-28. Sargent and Velde model the total charge by the government as a percentage $\sigma$, so that the amount of silver received back from the mint for each ounce is $1-\sigma$. SARGENT \& VELDE, supra note 10, at 20. That is received back in the form of coin: $(1-\sigma) / b$, where $b$ specifies a certain number of oz/penny. The mint equivalent determined the amount of metal in a coin by controlling the number of coins that would be struck from a given weight. 
other payments were increasingly levied and due in coin; public obligation continued in that sense to inform the demand for money. At the same time, money offered a disparate array of advantages to people, depending on their locations in English society. Put less affirmatively, some groups including merchants found it hard to avoid the mint, given the kind of wealth they transferred across borders.

More generally, coin held greater value than the amount of bullion it contained because its liquidity made it easier to use. But coin had to cover its own costs to be worth seeking in return for bullion. Early Englishmen brought metal to the mint when prices for goods in coin were low enough so that the gain in liquidity offered by coin was worth the charge for minting. In other words, prices reached a "minting point" when the increased buying power of each coin relative to raw silver compensated a user for the fact that he received fewer coins back from the mint than he would have if all the coins made from his silver had been returned to him. ${ }^{51}$ Theoretically, as Englishmen added coin to circulation, prices could rise above the minting point (coin could lose value). The flow of money to the mint would stop until prices fell again and minting more coin was once again worthwhile.

While free minting exploited the desire for liquidity to produce money, nothing in the system stopped people from destroying liquidity by melting money. That did not occur, however, as soon as prices rose above the minting point. People had, after all, minted coin only when prices were sufficiently low (coin was worth significantly more than bullion) to be worth the charge they had had to pay. But once coin had been paid for, it circulated with a value that could be compared directly to the metal within it. Not until prices in coin for goods rose high enough (the value of coin had dropped so far) that coin was no longer better than the silver it contained at buying goods would people begin to melt coin. That price, the breakpoint at which coin was worth only its value-by-weight, represented the "melting point," a price

51 Englishmen identified the minting point for coin by considering prices in coin for consumer goods, e.g., pennies/bread, compared to how much those goods would cost in silver. When prices fell, the value of coin was rising, making a trip to the mint more worthwhile. Tracking forward the way that Sargent and Velde model the situation, if the number of coins that can be procured from the mint is $(1-\sigma) / \mathrm{b}$ in pennies/oz and the relative price of consumption goods is $\phi$ in oz/good, then the price level (pennies/good) at which minting occurred is the number of coins that could be procured $((1-\sigma) / b)$ times the price of goods in silver $(\phi)$. SARGENT \& VELDE, supra note 10, at 20. If the charge for coin increased, in other words, prices in coin would have to drop farther relative to prices in silver before it was worth going to the mint. 
point for goods higher than the minting point. The "melting point" of coin, a price in coin/good, thus set an upper limit to the use of coin. ${ }^{52}$ And between that upper bound and the lower point at which people would mint coin, there was an interval which corresponded to the charge the government imposed for coin.

The free minting approach was in many ways shrewdly suited to its time. It brought in metal, transformed it into coin, and then fed coin into a system that treated it in a privileged way. The government issued coin as a unit of account, intended to trade at face value - although that commitment would encounter complexities. The Crown also made coin receivable in taxes and other payments. And whether or not formally ordained as legal tender for private use, coin effectively gained that status when political authorities recognized it as legitimately transferring value between individuals. The coin issued by the mint (supply) thus met an ensured demand. At the same time, the government prohibited competition to its currency. It refused to sanction transfers of private credit between strangers, limiting the use of notes and bonds, nor were such devices effective to pay off public obligations. Henry II likewise constricted the power of barons, bishops, or other feudal contenders to keep them from producing coins. He and his successors also fenced out foreign competitors, continuing the traditional bar on foreign coin that the early Anglo-Saxon rulers had put into place. The long and rocky English coastline made it possible to enforce the prohibition. Despite occasional lapses and an informal exception for Scottish coin, "for the most part English commerce was conducted in English coin." Finally, English authorities mobilized against counterfeiters, if not always successfully. The guerilla warfare consumed officials, pushing them to experiment with new technology, to adopt it and occasionally to resist it, on the ground that it could hinder, or help, those trying to pass off cheap duplicates. ${ }^{53}$

52 More precisely, people would melt coin when the coin had lost sufficient value that, even including the added cost of melting coin, the retrieved silver would be worth more than the coin.

53 On private credit's lack of negotiability, see for example Horsefield, supra note 45. On Henry's centralizing initiative, see Mayhew, supra note 13, at 132 \& passim. On the Crown's commitment to support the private exchange of coin by count and to discourage weighing of coin by the public, see $i d$. at 97-98. On the provision that silver, and eventually gold, be legal tender in private transactions, see 1 RoGERS Ruding, ANNAls of THE COINAGE OF GREAT BRITAIN AND ITS DEPENDENCIES 215 (London, J. Hearne 3d ed. 1840). For an example of the debt obligations of merchants in the late thirteenth and early fourteenth century that were filed in Chancery and enforced by that court, see Pamela Nightingale, Monetary Contraction and Mercantile Credit in Later Medieval England, 43 ECON. Hist. REV. 560 (1990). 
Where money - so exclusively defined - was scant, bullion could be expected to flow to the mint. Many transactions would benefit from the liquidity coin offered; those involved would take that currency when they could get it, keeping prices in coin low. The low prices would lead people to the mint. That is, prices would regularly reach the "minting point" and people would bring their metal in. They accepted along the way the charge imposed by the government for coin: the principle that people would pay for liquidity held, although it would configure when and where people brought their bullion to the mint, creating a complex geopolitics of coin.

Indeed, the free minting system operated for centuries as the central mechanism for producing coin. Until the second half of the seventeenth century, English sovereigns, like their European counterparts generally, charged for the money they put into circulation and relied on their populations to estimate how precious liquidity was to them.${ }^{54}$ Recoinages occurred much less frequently than they had earlier; monarchs declared them only when the coin had become seriously worn, or when they wanted to introduce new denominations. At those moments, in 1180, 1247, 1279, 1344-51, 1411, and 1464 , the lay population brought in its money, just as it had under the renovatio monetae. Otherwise however, people economized on renewing their coin and merchants became the main conduit for the metal to the mint. Required to use English coin to buy exports, they brought in the bullion and foreign coin generated by their trade. ${ }^{55}$

A Romanist in the sixteenth century, Bernardo Davanzati, would dream

The evaluation of the amount of foreign coin circulating is from Mayhew, supra note 13 , at $131-32$.

54 For accounts that explore the rising demand for money in circumstances where people perceived it as increasingly useful to pay public and private obligations, see, for example, Nicholas J. Mayhew, Population, Money Supply, and the Velocity of Circulation in England, 1300-1700, 48 ECON. Hist. REV. 238, 240 (1995); Peter H. Lindert, English Population, Wages, and Prices: 1541-1913, 15 J. INTERDISC. HIST. 609 (1985); Charles W. Calomiris, Institutional Failure, Monetary Scarcity, and the Depreciation of the Continental, 48 J. ECON. HIST. 47 (1988).

55 Mayhew, supra note 13, at 83-84 \& n.3. For the adoption of free minting throughout Europe, see SARGENT \& VELDE, supra note 10, at 128-29. The reduction in renewals correlated with a new practice at the Exchequer: It began to "blanch" coin brought in or require additional payment if the coin did not meet minimum quality standards. Id. at 90; S. Harvey, Royal Revenue and Domesday Terminology, 20 ECON. HIST. REV. 221 (1967). That practice would, indirectly, pressure people to take coin in to be reminted when it had reached a point of obvious wear. Insofar as the renovatio monetae system went without such a practice, it reinforces the assumption that the earlier method included a requirement that taxes be paid in new coin, which would not require an assay of value. 
that "metal should be worth as much in bullion as in coin, and be able to change from metal to money and money to metal without loss, like an amphibious animal." ${ }^{56}$ Insofar as it successfully produced coin from a commodity, free minting appeared to transmute metal directly into money. Contemporaries could identify the two, and later theorists could find in free minting an ancestor for the ideal commodity model of money. ${ }^{57}$ After all, free minting was designed to control fluctuations in the money stock by tying the quantity of coin to a physical anchor: as in the ideal commodity model, fixing an amount of metal per coin connected prices in coin to prices in the metal, creating a mechanism that would equilibrate the amount of currency in circulation according to the value of the metal. Changes in the real economy could then create changes in demand that would affect price and, in turn, the money stock. For example, greater economic activity could occur; given a static amount of coin, prices would fall. That would eventually produce minting. Here, the equilibrium between demand and supply would change, but it would change in response to real economic activity, as opposed to manipulations of the money stock.

But Bernardo Davanzati cast his comment as a counterfactual, imagining a world in which a simple and individuated choice created coin and, at that moment, money. As in the ideal commodity model, private responses to a single point, the price for goods in metal and in coin, would assumedly constitute the process. But free minting did not equilibrate the amount of coin in circulation by reference to an abstract touchstone; it orchestrated the process around a pair of relative prices for coin set by the government. That difference mattered in several ways.

First, as a matter of design, the structure exposed the action that public authorities took to define coin as a unit of account. The mint price and the mint equivalent each imported a measure for coin in metal. Recall that the mint price represented the number of coins that the government offered for metal at the mint. The mint equivalent was the number of coins that would be struck from that metal, a number that determined the value-by-weight of the coin. The difference between the two was the charge, in coin, for the government's intervention. The government began, then, by equating coin with a particular amount of metal, but that amount - and thus the relationship of coin to its commodity content - could and did change over time. The fact of the count, by contrast, would be more important than the

56 SARGENT \& VELDE, supra note 10, at 85 (quoting Bernardo Davanzati).

57 Sargent and Velde call it an approach that "imperfectly realized" that model. $I d$. at 11. 
amount of metal a unit initially contained. (In fact, while mint prices were published, mint equivalents were not, although only by considering them could a citizen calculate the amount of metal in a coin..$^{58}$ ) The process then put the unit of account into effect: the government charged and people paid for coin in that measure, one that was enumerated concretely before them. The transaction itself imported negotiability and taxation: the government minted a coin that it took (immediately) as a tax, supporting its transfer as a means of payment.

The government's charge itself had significance for the conversion of coin to money: it flagged the fact that creating money involved a wider public process that had to be supported. "Gross seigniorage" included production costs, but also the expense of judges who equated coin with money when they determined that it sufficed to satisfy debts and obligations, of officials who policed the borders to keep out foreign currencies, and of a bureaucracy that enforced taxes. ${ }^{59}$ As Innocent IV (1243-1254) put it, the government could rightfully charge for money, paying those who brought in bullion to get coin what "the metal or material from which it is made is worth," but with "necessary and useful expenses deducted." His recognition invited a debate over what expenses were "useful and necessary." There, commentators drew constricting lines, concerned about profits that sovereigns could skim for their own use. But they admitted as they argued that public need ultimately defined those lines. Innocent's words capture both the danger of acknowledging the sovereign's power to charge and the fact that money was a public project requiring political judgment:

We believe, however, that the king, by his right, and by the fact that money receives authority and general acceptance (authoritatem et communionem) from his effigy or mark, can make money of somewhat less, but not much less value than the metal or matter from which it is made. Therefore, in the first case, when he wants to diminish a money already made, we do not believe he can do so without the consent of the people, but with its consent we believe that he can, just as anyone is allowed to renounce his right .... And because the business of the king is considered to be the business of all, for this reason the consent of the majority of the notables of the kingdom suffices. ${ }^{60}$

58 REDISH, supra note 8, at 28.

59 I use the term "gross seigniorage" here to include all government charges, profit and production costs. See REDISH, supra note 8, at 27 \& n.10.

60 SARgENT \& Velde, supra note 10, at 91, 96 (citing CoRPUS JURIS CANONICI, LIBER EXTRA X 2.24.18, 1581, 1965, 2:130; 2.24.18; 1570, 285v). 
Second, the difference in design that set free minting apart from an ideal commodity model had an immediate and very practical consequence. Davanzati might fantasize magical transformations of substance, but the English population had been calculating how much coin cost them for centuries. From her review of mint data, Angela Redish argues that the demand for coin was highly elastic - the price charged for it greatly affected people's decision whether to go to the mint. Officials consequently kept the charge for coin relatively low; it was almost always less than 10 percent, and generally less than 5 percent. The sensitivity with which people registered increases in the price for coin suggests that its cost mattered greatly to them. Their complaints match their actions. Protesting the 1247 recoinage, Mathew Paris bore witness that "twenty shillings could scarcely be obtained from the money-changer's table for thirty [old shillings]" without great trouble and expense. ${ }^{61}$ Considering their cost, recoinages likely burdened people heavily, according to scholars of the period. And in-between recoinages, merchants regularly objected to the expense laid on them to convert foreign coin and bullion; the transition from the renovatio monetae to free minting had shifted the virtual tax imposed by the government's charge in ordinary times to them. ${ }^{62}$

Milton Friedman famously contended that a society should subsidize the creation of liquidity if it wanted the "optimum quantity" to circulate. According to his argument, money would reach all the transactions it could usefully facilitate when money came "free." And money would be "free" only when currency was produced by the government at its own cost - far from the medieval practice - and pitched by the government to circulate in an amount that predictably induced a gently deflationary trend ${ }^{63}$ The purpose of Friedman's effort was to purify price so that it could guide decisions about saving and spending, free from the distortions that could be caused as people factored in costs imposed by paying for liquidity (or for that matter, factored in bonuses carried by using liquidity).

Leaving aside whether it is possible to purify price as opposed to

61 On seigniorage rates, see REDISH, supra note 8, at 34, 51-53; see also FEAVEARYEAR, supra note 13, at $3 \&$ app. (suggesting rates between 2 and 12 percent). Paris's words come from 5 MATTHEW PARIS, CHRONICA MAJORA 18-19 (Henry Richards Luard ed., London, Rolls Series 1880), translated in D.W. Dykes, The Coinage of Richard Olof, 33 BRIT. Numismatic J. 73, 78 (1964), cited in Mayhew, supra note 13 , at 108.

62 See Mayhew, supra note 13, at 90, 108, 153, 167-69; NightingALE, supra note 44.

63 The cost of holding a non-interest-bearing medium (the loss of interest) would in that way be offset by the gain in value of money as prices fell. MILTON FRIEDMAN, The OPTIMUM QuANTITY OF MONEY 1-48 (2006). 
simply relocating the relations that influence it, Friedman's argument does effectively flag how much the cost of money matters to those holding it. It illuminates by contrast the free minting system, in which individuals assumed directly the cost of producing money, before and in addition to determining how much existing money they should hold. The government's charge for money up front thus determined the creation of liquidity, inducing it only when it was cost-effective for one user as opposed to being beneficial to a group. Nicholas Mayhew, teasing apart the sources of bullion for the late thirteenth and early fourteenth century, confirms that only the complaining merchants, who were required to change their foreign money into English coin, brought bullion to the mint in ordinary times; most individuals evidently avoided that expense. ${ }^{64}$ Tying minting to personal determinations to convert metal into coin put a drag on the system relative to other regimes for producing money. The strategy would chronically depress the amount of coin produced, independent of other problems that bedeviled medieval coin because of its commodity content. ${ }^{65}$

The specter of low liquidity haunted the governments and people of the medieval period. Mayhew maps the long drop in the "velocity" of money from 1300 to 1526, and then again between 1561 and 1670. The velocity of money is, as Mayhew puts it, "really only a measure of how hard the money supply is being called upon to work." It falls as demand for money, the willingness of people to hold it for the liquidity it offers, rises. ${ }^{66}$ The

64 Mayhew, supra note 13, at 83-84 \& n.3.

65 In turn, the destruction of liquidity would also be a matter of individualized calculation: it would occur when prices rose enough that any holder would melt his or her coin. Since that occurred, at least theoretically, only when users had factored in and recouped the government's charge for money (they would not melt coin until its value had fallen so far that it was worth only the amount of metal it contained), it would not pose the same problem as the drag on creating liquidity. Taken together, however, the drag on creating liquidity and the freedom to destroy it would both work to limit liquidity. (Note that there would be some qualification on destroying liquidity because people would have to pay for melting coin and retrieving the silver it contained.) $C f$. SARGENT \& VELDE, supra note 10, at 23-24 (explaining the irreversibility of making and melting coin in terms of arbitrage profits to individuals).

66 According to the quantity equation, Money $\mathrm{x}$ Velocity $=$ Price $\mathrm{x}$ Transactions, MV $=\mathrm{PT}$. The right side of the equation registers the number of times that goods are exchanged for money in a certain period of time, with $\mathrm{P}$ being the price for a typical transaction and $\mathrm{T}$ being the number of transactions. The PT total amounts to the total money value of all transactions. Since total transactions are hard to measure, $\mathrm{T}$ is often estimated at $\mathrm{Y}$, the total output of an economy. The left side of the quantity equation registers the quantity of money $(\mathrm{M})$ and the rate at which money circulates or changes hands in a given amount of time (V). For example, in an economy with a 
fact that demand for money rose for most of the English medieval and early modern period may simply reflect that, as the economy developed, money was more useful to have around. It is also consistent, however, with a latent need for money that could not be met until more coin was produced. Translated into everyday life, people may have wanted more of the medium that would make exchanges possible than they could get, at least if they had to pay for it directly. While macroeconomic theory would suggest that prices should fall in that case so that the lesser amount of money would service all the exchanges desired (prices would go down and transactions up), in the medieval world the indivisibility of denominations would have hindered that adjustment. Rather, much exchange may just have stayed outside the monetarized economy. ${ }^{67}$

Roger Ruding's Annals of the Coinage of Great Britain, a chronicle of official commentary and action on Britain's money "from the earliest period of authentic history to the reign of Victoria," suggests such a drought. Petitions of the Commons, complaints of merchants, and the desperate attempts of sovereigns to increase the amount of coin circulating in the kingdom - all raise the alarm again and again in its pages. An entry about the year 1346, for example, captures the Commons's plea "that, on account of the great scarcity of coins in the realm, the king would be pleased to ordain that money should be more frequently coined, and that the mints should be open in all places where they were accustomed to be." The king agreed, and then accepted a suggestion that he police the Lombard merchants in their efforts to contract for purchases in foreign coin. The merchants meanwhile

large $\mathrm{M}$, money would have to change hands less frequently than with a small $\mathrm{M}$ in order to service the total money value of transactions. See generally MANKIW, supra note 2, at 161-63. The demand for money tracks that relationship: in economies with a large quantity of money or $\mathrm{M}$, people are holding more money relative to the total money value of transactions: $\mathrm{D}=\mathrm{M} / \mathrm{PT}$. That is, "demand" or D as represented by the quantity equation, is larger. $\mathrm{D}$ is, in other words, the inverse of velocity.

67 Mayhew, supra note 54, at 240; Lindert, supra note 54; JAMES C. RILEY \& JOHN J. MCCUSKER, Money Supply, Economic Growth, and the Quantity Theory of Money: France, 1650-1788, 20 EXPLORATIONS ECON. HIST. 274 (1983). In the late eleventh century, the English money supply amounted to about 4d (shillings) per person; by 1300 , it was at about 36d/person. MAYHEW, supra note 46, at 5, 17. Mayhew and Spufford consider the effect of that increase on daily life and commercial exchange, in id. at 15-20; SPUFFORD, supra note 17, at 109-263. For the increase in the money supply from the late thirteenth to the early sixteenth century, see Mayhew, supra note 57, at 244, 250-51. After the Great Debasement of the sixteenth century disrupted the pattern of a steadily increasing demand for liquidity, Englishmen (and Europeans more generally) reverted to that tendency throughout the modern period, from 1700 to 1900 . In the modern period, the government was subsidizing the creation of money. 
demanded a judicial inquiry, charging that the mint-masters had been too slow to issue new coin for bullion and asking "that they might receive their silver again." 68 In retrospect, the Middle Ages appears a parched period, one in which the chronic dearth of a currency that would allow transactions to be measured by money confined people to other strategies of exchange or drew them there. ${ }^{69}$

The realities of free minting departed from the ideal commodity model in a third way. The free minting system distinguished money from a commodity by charging for the extra service of coining it and making it money. At the same time, it assimilated money to a commodity by assuming that coins should hold value proportionate to their value as metal. Striking a balance that maintained both commitments turned out to be enormously difficult. To resolve the instabilities in the system, the English, like their European neighbors, slowly and steadily diluted the commodity base of coin.

\section{The Commodity Commitment And Its Counterintuitive Cure: Diluting Coin}

As an Anglo-Saxon measure of value, the barleycorn suggested the way that community actually created coin by selecting and measuring out a familiar amount of metal, and making tokens it would then transform into money. But there is another lesson to be drawn from the barleycorn, one that presents another side of early coin. The barleycorn was, at the bottom of it all, a particular measure of weight. And as a measure of weight, it highlighted the material that it parced. Coin, in this system, could easily have come to seem the commodity that it contained. ${ }^{70}$

From the time of Offa's reign until the late thirteenth century, English

68 RUDING, supra note 53, at 215, 223-24.

69 For the secondary role of private credit in redressing the liquidity problem, see Nightingale, supra note 53; DAVIES, supra note 24, at 169; Mayhew, supra note 54, at 253-54. For the way that the high pressure put on low denominations shaped the character of private credit in England, see Christine Desan, The Social Stratigraphy of Coin and Credit (Aug. 19, 2009) (unpublished manuscript, on file with author).

70 William I stabilized the weight of pennies at approximately 1.4 grams, where it remained until the end of the thirteenth century. MAYHEW, supra note 46, at 3. By comparison, English pennies in the ninth century were somewhat heavier (about 1.55 grams), as were Charlemagne's pennies (1.7 grams). REDISH, supra note 8, at 4, 47. Pennies lost weight between the late thirteenth and mid-fourteenth centuries (1.4 to 1.2 grams), the start of a trend that continued through the seventeenth century. See id. at $47 \&$ n. 2 . 
mints made only one coin, the silver penny. People in need of smaller change cut pennies in half and even into fourths or "farthings." As for larger denominations, they had to wait until midway through the next century. As Nicholas Mayhew describes the early age, big payments "involved bags, sacks, and sometimes barrel-loads of pennies." Money traveled across the land in convoys under armed guard; its presence was "very tangible, physical," a material representation of value that was "heavy bulky, and vulnerable."71

The very materiality of medieval money invited participants to identify it with the substance that it incorporated. In this world, money was a visceral matter - the silver that moved across the country to pay the army, the pure metal that contrasted with counterfeits and foreign "false" coin, the sterling (probably from the Middle English root "ster-" for strength) that gave the English penny repute as a stable currency. ${ }^{72}$

In a one-denomination system, moreover, the value of coin could remain smoothly consonant with the relative value of silver. Prices in pennies diverged from prices in silver - thus coins generally bought more than the amount of silver in coin bought, and authorities intended coin to travel "by tale" or by count, rather than by weight of coin. But as long as pennies functioned fairly predictably to track silver values, participants did not need to theorize that divergence and could suppress any dissonance created by their observation of tale value. ${ }^{73}$

At the same blunt level, coins could be conflated with a metal commodity because the metal in money gave it a default value - one could always melt the coin and retrieve bullion. Money could seem interchangeable with metal, as if each were a commodity different only in form. Beneath the equation, there remained a sleight of hand: just as the value of pennies held a secret complexity, tracking that of silver but diverging from it, money was not actually interchangeable with bullion but converted from it. Convertibility depended on the whole enterprise of minting coin and privileging it into money (or destroying coin and disabling it as money). The aim was to produce a unit of account that carried value and paid off debts, rather than

71 MAYHEW, supra note 46, at 20; Mayhew, supra note 13, at 101; SARGENT \& VELDE, supra note 10, at 132. Short experiments with gold coins in the thirteenth century - a penny in 1257 and a groat in 1279 - failed. The Crown would not turn to gold for money again until 1343. REDISH, supra note 8, at 48.

72 For the "false" coin terminology applied to the foreign currency that occasionally invaded England, see SARGENT \& VELDE, supra note 10, at 132. For the etymology of sterling, see MAYHEW, supra note 46, at 2.

73 See SARGENT \& VELDE, supra note 10, at 16-18, 69-71, 73-99. 
to provide a substitute on order for silver. But the intuition that identified money as a commodity was easier and more available than recognizing its more dynamic definition, just as silver tokens were more obvious than the process that produced them.

Drawing on that inheritance, early participants at first simply multiplied by amounts of metal when they began expanding the number of denominations. It seemed, at the outset, a straightforward solution to a straightforward problem. Medieval Europe boomed in the thirteenth century - cities grew, economic exchange expanded, local minting flourished on the basis of newly discovered silver mines. The activity bumped up against the limits of the penny; it was too large to capture the thousands of small deals that people now conceived, and it was too small for the larger transactions, military and mercantile, that governments and laypersons began to attempt more commonly. The solution seemed clear: like other Europeans, the English created both smaller and larger coins. Silver farthings and halfpennies came first, followed by the groat worth four pence. Officials assumed that every coin should be made of metal and that the amount it contained should correspond exactly to its relative value as a currency. English groats, for example, contained precisely four times as much silver as the penny. ${ }^{74}$

It seemed appropriate to apply the same logic even further - medieval communities were soon to reinvent gold coin. As Angela Redish so lucidly recounts, silver could not answer the burgeoning demand for spending on different scales. When it was fine, the metal was so precious that it had to be minted to a very small size to provide small change - a thirteenth-century silver penny was less than two-thirds the weight of an American dime. Farthings and halfpennies could easily become too tiny for safekeeping and too brittle to stamp. In a world where wages amounted to two to three cents a day, the problem was critical. At the other extreme, coins larger than 31 grams, or worth 22 pennies, were big enough to invite counterfeiting cheap fillings were harder to detect in a larger package. Adding metals of lesser or greater quality to the lineup offered a way to increase the currency's range. The English refused for centuries to alloy their small silver coin, a decision that left everyday exchange bereft for just as long. But they began minting the gold noble in the mid-fourteenth century, at a moment when European silver mines had begun to run dry. The noble was worth 80 pennies and was designed to have a mint equivalent that, at the proper

74 MAYHEW, supra note 46, at 20; Mayhew, supra note 13, at 101; SARGENT \& VELDE, supra note 10 , at 132 ; REDISH, supra note 8 , at 48 . The first concerted issues of fractional denominations began under Edward I, in 1279. 
ratio of gold to silver prices on the commodity market, matched the mint equivalent of 80 silver pennies. If money were, indeed, a commodity, then it should be scaled according to a hierarchy of denominations, each in a quantity of metal proportionate to its monetary value. ${ }^{75}$

But the relation between money and its physical form was not so straightforward as those elaborating it at first assumed. Even as the early English treated money as a commodity, merely coined silver, they had recognized and exploited the faculty, liquidity, that distinguished it from silver: the "free minting" method of producing coin relied on individual determinations about the advantages that liquidity brought. The simple world, when money was made of one metal and one denomination, had not stressed the discrepancy. There, the divergence of value between pennies and silver was no problem; it was in fact the motor of the system. And the fact that everyone paid only in pennies flattened disputes about values paid - the poor did not use money for small matters, and the wealthy had no choice about the denomination they used. They could not strategize ways to control payment options in a system that had only one category for accounting, as they would if other types of coin were available. ${ }^{76}$

All of that changed when the English and their European neighbors began enhancing liquidity, adding denominations and metals to suit exchange of different sizes. At the moment that medieval communities, based on their experience with the penny, elaborated a hierarchy of coins configured by commodity values, they engineered a conflicting commitment into a system that turned on the liquidity value of money. The fault line destabilized medieval money, pitting a medium valued because it could be counted, circulated, and used to pay off a debt against a commodity content valued for its physical properties.

The structure of medieval money made the problem conspicuous, at least in hindsight. Recall that English authorities imposed a fee for money - the

75 On the size of silver coin and the refusal of the English to use alloys, see REDISH, supra note 8 , at $18-24,48$. The wage figure of $2.2 \mathrm{~d}$ is for 1349 and is from SARGENT \& VELDE, supra note 10 , at 48 . On the turn to gold, including experiments with a gold penny in 1257, and a gold florin in 1343, see MAYHEW, supra note 46, at 23, 32; and for an example of the way gold and silver mint equivalents were supposed to equate, see REDISH, supra note 8, at 27-29. On the commitment of England to full-bodied coinage of proportionate intrinsic value, see Mayhew, supra note 13, at 130; REDISH, supra note 8, at 48-49; SARGENT \& VELDE, supra note 10, at 4-5.

76 See Cipolla, supra note 23, at 38-51. Medieval jurists did, however, grapple with problems of devaluation and demonetarization. See SARGENT \& VELDE, supra note 10 , at 69-99. 
gross seigniorage that the government charged those who brought bullion to the mint. That amount represented how much people were willing to pay for liquidity: when coin bought goods at a sufficiently low price compared to bullion, people assumed the cost imposed by the government to get coin. The value of liquidity literally drove a wedge between the commodity value of silver and its value coined into money.

That wedge created the tectonics of medieval money, grinding shifts in the supply of coin that was available for different deals and to different parts of the population. The problems occurred at both the practical and conceptual levels, catalyzing governments constantly to recalibrate the relationship between money and its commodity content. The overall trend was clear: participants sought to calm the turbulence and reestablish a flow of liquidity by diluting their commitment to the commodity base of money. Their struggle helped define the buried dynamics of the medieval political economy. As importantly, it slowly expanded the amount of money available. And in the process, it disproved the identity of money and the commodity, obtaining the first by jettisoning a commitment to the second.

The practical problem created by the commodity base of medieval coin was that every coin - old or new, large denomination or small denomination, silver or gold - had a counted value (its value as money) and a weighed value (its value as a commodity). As the wedge makes clear, the ratio of counted to weighed value for each coin had to correspond exactly to the ratio of counted to weighed value of every other coin, proportionate to each coin's intended place in the monetary hierarchy. If the ratios did not correspond, people would prefer to hold the coin of relatively greater weight because although it was worth the same amount as coin when counted, it offered more value as a commodity. Depending on the circumstances, people might hoard, melt, or export the coin that offered greater commodity value. In any case, as people began distinguishing coins by weight, they would disrupt the way money flowed in their communities. ${ }^{77}$

The very qualities that attached to a commodity - its tendency to wear away, its appeal as an international resource, the fact that markets for different metals changed over time - made it likely that the close correspondence between relative values across many coins that was necessary to preserve a working system of money on the medieval theory would fail time and again. We can start with the most mundane issue, wear and tear on

77 The effect has often been lumped into the assumption that "poor money drives out good," known as "Gresham's Law." In fact, it appears that people reacted in different ways to money with greater commodity value. REDISH, supra note 8, at 32-33. 
coin, work through the intricacies of bimetallic arbitrage, and reach the relentless competition between sovereigns to attract metal to their mints. Each phenomenon unleashed the same basic capacity to destabilize coin as it upset the intended equivalence across coins in their counted to weighed value.

Wear still makes its familiar mark today, especially on softer coin. Throughout the second half of the twentieth century, a handful of American coins chanced to contain a beautiful holdover from an earlier decade - the liberty dime was 90 percent silver and carried Liberty in profile, wearing a winged cap. A patina was part of the dime's grace, along with the way the edges of its images were softly fading away. The coin of the Middle Ages, made with an earlier technology, wore even more relentlessly and surely less romantically as it passed from hand to hand. According to Nicholas Mayhew, coin that had circulated for half a century or so had to be replaced, having lost about 2 percent of its content per decade. Clippers and shavers, stealing little bits of the coin's edge to sell as bullion, had often taken even more metal. ${ }^{78}$

As old coin continued to circulate and new coin was issued, the problem arose that each carried a different amount of metal relative to its counted value. In macroeconomic vocabulary, new coin would inevitably be "undervalued." It contained more metal than its older counterpart; effectively, it had a lower mint equivalent - fewer coins of its weight could be struck from a given amount of silver. The problem could have occurred within a one-coin system, but the early English system of renovatio monetae had largely obviated it with its regular renewals. After the mid-twelfth century, however, new pennies would more regularly have diverged in weight from old.

The move to more denominations added to the problem. Coin of different size changed hands at different rates. Small change would move more quickly and would be especially vulnerable to wear. Testing their coin in 1798, the English found that crowns in circulation were 3.3 percent lighter than at issue, while shillings were a full 25 percent lighter. According to that pattern, new issues of smaller coin would more often have dramatically different mint equivalents from those of older issues, disrupting the critical supplies of small change. In addition, the mint equivalent (or counted value relative to commodity weight) of smaller denominations, here shillings,

78 See Mayhew, supra note 13, at 137; MAYHEw, supra note 46, at 44. REDISH, supra note 8, at 54-61 reviews the long delay before the English adopted minting technologies that significantly reduced clipping in the late seventeenth century. 
would fall out of sync with those of larger coin. Larger coin would become relatively "undervalued" or worth relatively more by weight given their value by count..$^{79}$

Undervaluation so notoriously afflicted early coin that the English long ago dubbed its effects categorically. According to "Gresham's Law," anyone holding undervalued coin could be expected to save it for those transactions where money would be valued by weight, not count - predominantly international exchange. "Bad money," the light coin worn down by use for instance, would drive out "good money," the heavier undervalued coin that people exported. The more severe the undervaluation, the faster the hemorrhage of money. Gresham's Law may draw the picture too starkly. Some current macroeconomists argue that communities tended to keep larger undervalued coin circulating at a premium (that is, circulating it by weight, not by count), while melting or exporting small undervalued coin; others find more ambiguous patterns ${ }^{80}$ But whether people reacted predictably or in their own erratic fashion, undervaluation chronically bedeviled the attempts of medieval communities to create a regular flow of liquidity.

When the English innovated a gold currency, they multiplied the sources of instability. Their bimetallic system, like others, was designed to circulate coins in silver and gold that had a common unit of account: both the silver groat and gold "unite," for example, were convertible into sterling pennies or shillings. The trick was to set the silver and gold content of coins that had the same counted value so that its ratio tracked the ratio of silver to gold prices on the world commodity market. At that ratio, gold and silver had identical commodity values relative to their counted value, i.e., the same mint equivalents. Users would mint, melt, and use both silver and gold coins according to the same calculations. Their river of liquidity would run smoothly, while benefiting from a whole new reservoir of metal.

The catch was that setting a silver to gold ratio for coin's content that was accurate in the long term was basically impossible. Mint officials might call the ratio according to the commodity market for metal exactly right on the day that coin was issued - but changes in the market would moot their judgment. If gold rose in value, for example, a gold coin that had been worth the same as a silver coin by count would be undervalued because it was now worth more by content. The discrepancy would disrupt domestic

79 REDISH, supra note 8, at 28-29. As Redish defines the mint equivalent, it is the value of a coin, divided by the product of its fineness and its weight. See also SARGENT \& VELDE, supra note 10, at 22.

80 REDISH, supra note 8, at 30-33 (reviewing the current debate); see also SARGENT \& VELDE, supra note 10, 261-90. 
patterns of spending, just as it did when people melted heavier pennies or dumped old ones. But bimetallic discrepancies triggered flows of silver and gold across the border even more readily. Merchants aware of gold and silver prices abroad would pay in whichever coin held the greatest value there. In the meantime, their partners would send back the other metal, which had a relatively greater value in England. That dynamic could empty a country of silver or gold, whichever was undervalued in it. Predictably, the movement would be more radical when the undervaluation was more severe. At a certain point, it became profitable for arbitrageurs to export a coin containing undervalued metal - say silver - melt it abroad, sell it at its value there for a profit, buy gold, and import that metal back home for minting. ${ }^{81}$

Bimetallic flows left a particular twist in their wake, one that savaged medieval populations in a way that is invisible when liquidity remains an abstract issue. Undervaluing one metal for a long time - and silver was the metal most often undervalued in the fourteenth and fifteenth centuries - desiccated the supply of that bullion to the mint. From the 1350s to the 1420s, and then again for most of the fifteenth century, gold poured in for coining at a much higher rate than silver. The disproportionate supply meant that gold denominations predominated: the coin brought in during a 1460s recoinage, for example, was two-thirds gold coin to silver. The drama for people in everyday circumstances, as Mayhew points out, is that the dominance of gold made the currency "extremely top-heavy." Gold coin lubricated only the largest exchanges - three gold coins might make up a pound, the equivalent of 240 silver pennies. ${ }^{82}$ The distortion put people at the bottom of the scale of economic activity at the greatest dearth for an accessible medium.

The commodity content of coin engendered yet another source of undervaluation, one that followed from the very appeal of silver and gold

81 MAYHEW, supra note 46, at 32-34; REDISH, supra note 8, at 29-32. Arbitrageurs would act when the mint equivalent of silver was less than the relative mint price of gold, adjusted by the price ratio of gold: silver on the world market. At that point, prices (each denominated in the same units of account but payable in different metals) were such that they would induce people to melt silver and to mint gold. Arbitrageurs could pay for the minting costs of money and still come out ahead. As Redish points out, their calculus would also have been affected by other costs left out here, like the cost of moving money and melting it. REDISH, supra note 8 , at 31-32.

82 MAYHEw, supra note 46, at 33; see also REDISH, supra note 8, at 107-35. Over the sixteenth century, and certain parts of the seventeenth, gold was more chronically undervalued. $I d$. at $43-44$. 
as precious metals that held value as coin. When European communities selected those metals as the common touchstones for liquidity, they created competition over them between themselves. The scramble usually started when one sovereign raised the mint price it offered to those bringing in coin. While it could reduce the amount it charged customers and leave the mint equivalent undisturbed, more often it slightly lightened the new coin. Until the difference came to light, the strategy would attract bullion from neighboring countries. And insofar as coins like pennies and derniers continued to pass interchangeably, a small debasement might work indefinitely. The technique could be used across an entire coinage, and across both metals. It operated to leave another sovereign's coin effectively undervalued: that coin carried more metal for comparable counted value than the debasing neighbor's coin. ${ }^{83}$

The competition over metal in Europe was intense. Medieval communities began at a baseline of low liquidity. Many exchanges probably went unmonetarized by the coin, arbitrarily fitted to metal, that countries began to issue. Economists would point out that prices could drop to allow a lesser money supply to serve all the transactions that people wanted to make with money. But that solution assumes an infinitely divisible money supply; deflation without lesser denominations instead simply left more small deals without a coin small enough to accommodate them. It generated popular discontent and slowed economic activities, as borrowers drew back, fearing that loans would be harder to repay as money gained in value. And holding a hard line on the metal content of money left a country's currency undervalued, if other countries debased their coin. Independent, then, of the "bullion famines" that most scholars find in the later Middle Ages, communities thirsty for more liquidity had every reason to debase their coinage. Their incentive would only increase as more economic activity fed the demand for money or as supplies of bullion did indeed fall. ${ }^{84}$ Insofar as it attracted metal from other countries, debasing coin increased the absolute

83 REDISH, supra note 8, at 47-48. For occasions on which English sovereigns debated or actually reduced their gross seigniorage take without disturbing the mint equivalent, see Mayhew, supra note 13, at 176; DAVIES, supra note 24, at 192-93.

84 Scholars have traditionally assumed that a "bullion famine" gripped England and the continent in the late Middle Ages. Europeans had exhausted local mines and a chronic balance of trade problem drained silver and gold to the East. Recent work has disputed that such a famine could have lasted indefinitely because, if the supply of bullion had remained short, prices in metal should have fallen along with prices in coin made out of it. Insofar as the country was operating as a closed economy, the change in prices would be long-lasting (as far as the impact of monetary quantity was concerned); the problems that haunted the English should have been soluble 
supply of metal that came into the mint. At the same time, it recycled even domestic supplies, replacing fewer units of a more valuable currency with more units of a less valuable one. ${ }^{85}$

As sovereigns debased their own coin, they left their neighbors with little choice but to correct the undervaluation visited upon their own coinage. Competitive debasements were especially common on the Continent, where small price inducements at the mint and slightly higher mint equivalents for coins that generally passed at the same counted value as others could easily draw metal across borders. But the effects of competitive debasements occasionally reached England, drawing bullion away despite the longer distance it would have to travel and the claim that English coin, if heavier in weight, had a higher value by count as well. When they recognized European debasements as interfering too drastically with their bullion supply, the

with the invention of new and lower denominations. (Here, as the value of bullion rose, the sovereign could be expected to offer new denominations that created mint equivalents in smaller units of account.) Insofar as the country was linked into global networks, low prices would eventually have induced a flow of bullion towards England in return for the goods available at the newly deflated prices. In either case, or to the extent that the economy responded in either fashion, the bullion famine would have eased. For the narrative of bullion famine, see for example SPUFFORD, supra note 17, at 339-62. For the response, see SARGENT \& VELDE, supra note 10, at 124-35; Nathan Sussman, The Late Medieval Bullion Famine Reconsidered, 58 J. ECON. Hist. 126 (1998). According to O'Rourke and Williamson, however, price convergence in goods did not occur until the nineteenth century. Kevin $\mathrm{H}$. O'Rourke \& Jeffrey G. Williamson, When Did Globalization Begin?, 6 EUR. REV. ECON. Hist. 23 (2002); Kevin H. O'Rourke \& Jeffrey G. Williamson, Once More, When Did Globalization Begin?, 8 Eur. REV. ECON. HIST. 109 (2004). O'Rourke and Williamson's work focuses on commodity prices and is suggestive only on the price convergence of precious metals. See id. at 116. Extrapolating from their findings however, shortages of bullion could have remained a local phenomenon. In that case, debasement may have been the response that sovereigns preferred, for the reasons in the text, to deflation in facing what would have been, after all, a bullion famine in Europe. The relative effect of debasement on the terms of trade would, in any case, have been like a price drop caused by a loss of bullion: debasement should have cheapened exports and made imports more expensive. But if world markets were not well integrated, those trends may not have induced responses that changed the balance of trade.

85 See MAYHEW, supra note 46, at 10. For impact of that strategy (or, more precisely, the impact of the absence of that strategy) on social and economic life, see for example Desan, supra note 69. 
English raised the mint equivalent of their own coin, debasing the unit of account in terms of its silver content. ${ }^{86}$

The type of undervaluation created by competitive debasement had, then, a solution that those suffering from it consistently adopted: facing a neighbor that lightened its own coin, they responsively depreciated their money. More striking is the fact that English sovereigns, like the rest of the European community, almost always responded the same way when they faced other undervaluation problems. Whether they wanted to repair the wear on coins or correct the ratio of silver to gold that coin contained given changes in the commodity markets for those metals, medieval authorities depreciated the undervalued coin: they decreased the precious metal in the coin, bringing its commodity worth down relative to its counted value, so that the coin was no longer more attractive to hold than other, more highly valued, denominations or issues.

The same solution worked as well against a last source of instability. The "big problem of small change" stemmed from a lurking flaw in the very logic that cast the value of liquidity as proportionate to the value of a commodity. Then as now, people needed money to service small as well as large transactions. In addition, the prices that prevailed in medieval England defined everyday wages and living expenses at a level that required low denomination coins. The capacity of small change - and only small change - to facilitate even the smallest of those exchanges set it apart from other denominations. Put another way, it gave small change a higher liquidity value relative to its metal content than coins made of stuff that was worth more in amount or kind of metal. That discrepancy changed the prices that different denominations could command, and thus the moments at which they reached their melting points. Insofar as small coin depreciated against larger denominations, it was melted out of circulation, worsening the problem. Minting policies exacerbated the situation: authorities produced relatively fewer small coins than larger ones, given their higher relative cost per unit produced. Add to that the facts that wear took an especial toll on small change and that bimetallic flows brought gold to England at the expense of silver for much of the late Middle Ages. Shortages of small change seared the poorer medieval population. ${ }^{87}$

86 See for example the alterations to coin weight in 1344-1351 described by Mayhew, supra note 13, at $165,168$.

87 SARGENT \& VELDE, supra note 10, at 15-36, 131-35. Sargent and Velde argue that, because small coin held a higher liquidity value than larger coin, people were willing to hold it even when prices rose in small denomination coin. Put another way, the value of larger coin appreciated against small coin. In everyday life, that effect may 
If moderns imagine that commodity coin was a simple matter, they mistake the reality that their medieval counterparts faced, with its wrenching shifts, bewildering complexities, and seemingly insoluble instabilities. The relative undervaluation of coin, international competition for metal, the big problem of small change - all created crises that skewed monetary value along one axis or another. The depreciation of coin's commodity content offered a cure for all of those problems. Like them, it also shaped the medieval world.

English authorities could dilute the metal value of money in several ways. Sometimes they debased new coin, decreasing its weight or fineness. That strategy would leave each coin with a lower metal content (or raise the mint equivalent, i.e., the number of coins that could be struck from a certain amount of metal). Less commonly, medieval communities enhanced or "cried up" the value of the undervalued coin. They would declare each new penny to be worth two pence, for example, effectively halving the amount of metal per pence. And occasionally, officials would insert a new coin into the hierarchy of denominations, one with a higher mint equivalent for its counted value.

Even at broad brush, the trend is clear: between 1343 and 1666, the amount of silver in English coin fell by more than 60 percent, the amount of gold in coin by slightly more. ${ }^{88}$ Davies estimates that depreciations occurred three to four times a century. Redish's data on mint equivalents suggest clusters of depreciation that average out to one per decade, while Mayhew suggests interventions designed to cure wear and tear every 60 years, interspersed with occasional depreciations to respond to competitive debasements in Europe. ${ }^{89}$

Medieval communities could have adopted solutions that avoided depreciating coin. They might have raised the metal content of overvalued coin, calling in old pennies, for example, and reminting them at a lower mint equivalent. Likewise, they might have "cried down" circulating coinage, declaring old pennies to be worth only halfpence, again effectively raising

have occurred as buyers successfully offered larger denominations to buy items at lower prices, because no one could or would part with smaller coin to do so. On the problem of coin shortages, see also REDISH, supra note 8, at 107-15; SPUFFORD, supra note 17, at 339-41, 344-38, 356-62.

88 REDISH, supra note 8, at 89-90. According to Redish's figures, the sterling $£$ (the mint equivalent) contained .769 troy lbs pure silver in 1343, and .299 troy lbs pure silver in 1666 , a 61.1 percent drop. The sterling $£$ (the mint equivalent) contained .06 troy lbs pure gold in 1343 and .022 troy lbs pure gold in 1666, a 63 percent drop. Rates of depreciation were significantly higher in the rest of Europe.

89 See DAVIES, supra note 24, at 170; REDISH, supra note 8, at 89-92; MAYHEW, supra note 46 , at 44 . 
the amount of metal per unit of account. Yet medieval authorities very rarely adopted either solution - England's decision in 1696 to appreciate its coin was exceptional. ${ }^{90}$

The practice of medieval communities - England among them - to solve their coinage problems by diluting rather than strengthening the commodity content of its coin was remarkably consistent over time. Depreciating coin imposed fewer costs directly on those bringing in old money; they would otherwise have exchanged coin worth a greater amount by count for fewer full-bodied coins. To be sure, depreciating coin exacted its cost in other ways: prices would rise as the mint cut more coins from the same amount of metal, all else being equal. But all else may not have been equal in medieval society: the thirst of people for liquidity absorbed the increasing supply of money, as people used available coin for a larger number of transactions. Prices did not increase in a sustained way between the early fourteenth and the early sixteenth century. ${ }^{91}$

That circumstance suggests the more lasting reason that medieval communities - England among them - diluted their coin. Economic exchange was not an abstract, one that could be conducted with an absolute, a measure made out of a static amount of commodity. The progressive depreciation of coin during the Middle Ages hewed to another logic altogether. It acted out the notion that silver and gold were catalysts for the creation of liquidity, not commodities that constituted it. Indeed, once a commodity had been identified as the referent for money, it ceased to perform as a normal commodity. Its value was affected by the way it was produced, the range of exchange it allowed, the kinds of credit it engendered to expand in ambit, the strength of the measures that policed its circulation.

A commodity was not acting here as a universal equivalent with any independent value. Rather, it was acting as a mechanism, an instrument of alchemy, one that produced a very particular medium because of the way public and private organized to make it into money. That medium in turn irrigated a domestic and international landscape, as it flowed to

90 See generally REDISH, supra note 8, at 33-34.

91 For the price index, see MAYHEW, supra note 46, at 258-59. The stability of medieval prices occurred despite the fact that the value of silver and gold rose, as Angela Redish puts it, "systematically." REDISH, supra note 8, at 43-44. By the time of the 1696 recoinage, the government had assumed the costs of minting. Its expense for the recoinage was enormous. For advocacy of depreciation as beneficial, see DAVIES supra note 24, at 172-73; MAYHEW, supra note 46, at 26-38. On the recoinage debate, see SARGENT \& VELDE, supra note 10, at 276-90. 
certain hands and with certain rhythms. England's money and its market, far from entities that sprang spontaneously or apolitically into being, thus "made" each other, creating a political economy that waits to be decoded in that light. 
